\title{
AGRICULTURAL
} ECONOMICS

\section{Structural adjustment and soil degradation in Tanzania A CGE model approach with endogenous soil productivity}

\author{
Henrik Wiig ${ }^{\mathrm{a}, *}$, Jens B. Aune ${ }^{\mathrm{b}}$, Solveig Glomsrød ${ }^{\mathrm{c}}$, Vegard Iversen ${ }^{\mathrm{b}, 1}$ \\ a Section for International Economics, Norwegian Institute of International Affairs, \\ P.O. Box 8159 Dep., N-0033 Oslo, Norway \\ ${ }^{\mathrm{b}}$ Noragric, Agricultural University of Norway, Oslo, Norway \\ ${ }^{\mathrm{c}}$ Research Department, Statistics Norway, Oslo, Norway
}

Received 19 March 1999; received in revised form 2 January 2000; accepted 8 March 2000

\begin{abstract}
In this paper, a model of the nitrogen cycle in the soil is incorporated in a Computable General Equilibrium (CGE) model of the Tanzanian economy, thus establishing a two-way link between the environment and the economy. For a given level of natural soil productivity, profit-maximising farmers choose input levels - and hence production volumes - which in turn influence soil productivity in the following years through the recycling of nitrogen from the residues of roots and stover and the degree of erosion. The model is used to simulate the effects of typical structural adjustment policies like a reduction in agro-chemicals' subsidies, reduced implicit export tax rate etc. After 10 years, the result of a joint implementation is a 9\% higher Gross Domestic Product (GDP) level compared to the baseline scenario. The effect of soil degradation is found to represent a reduction in the GDP level of more than 5\% for the same time period. ( 2001 Elsevier Science B.V. All rights reserved.
\end{abstract}

JEL classification: C68; Q16; Q24

Keywords: CGE model; Soil degradation; Economic growth; Structural adjustment

\section{Introduction}

"Agriculture is the foundation of the Tanzanian economy, providing employment, food and exports. Some $84 \%$ of the population is employed in agriculture, providing $61 \%$ of both Gross Domestic Product (GDP) and merchandise exports." (World Bank,

\footnotetext{
* Corresponding author. Tel.: +47-22056541; fax: +47-22177015; http://www.nupi.no/SEKSJON/oecon/ henrik.htm.

E-mail address: henrik.wiig@nupi.no (H. Wiig).

${ }^{1}$ Present address: School of Development Studies, University of East Anglia, Norwich, Norfolk, NR4 7TJ, UK.
}

1994). Agriculture might become the engine for export-led growth, which is advocated by the International Monetary Fund (IMF) and the World Bank through the conditions in the Structural Adjustment Programmes (SAPs) of the 1990s. The traditional export crops - cotton, coffee, tea, tobacco and cashew nuts - constitute $34 \%$ of foreign exchange earnings. Export of maize and staple foods to neighbouring countries might reach significant levels if trade is encouraged (Grepperud and Wiig, 1999).

An important objection to agricultural exports as the locomotive of economic growth is environmental and economic sustainability. Tanzanian agriculture is characterised by small-scale farming where the average 
farm size is just 0.9 ha (World Bank, 1994) and there is restricted access to fertilisers and modern production inputs. The most common production technique until now has been fallow and rotation agriculture. Each plot is merely cultivated for some years before it is left idle in order to recover the nutrient balance. This is now changing. Population pressure, increased exports and migration to urban centres which entails market-based consumption of food enforce persistent farming. The result may be soil erosion and depletion of nutrients. Yields might decline every year if the natural nutrients in the soil are not replaced artificially with commercial fertilisers or natural sources like mulch, cow dung etc. Tropical soils are shallow and prone to erosion. Furthermore, agriculture is often the most important economic sector in third world countries and soil degradation will hence have a major impact on people's real consumption opportunities. This emphasises the need for integrated ecology and economy studies in developing countries.

A common approach in environmental and agriculture economics has comprised static or dynamic profit maximising models with exogenous prices, where the stock of natural resources is related to production volume (Copeland, 1994; Innes and Ardila, 1994; Lopez, 1994; Hofkes, 1996; Barret, 1997; Kruseman and Bade, 1998; Pender, 1998; Vickner et al., 1998). The first-order effect of more inputs is an increase in production. But it also implies a reduction in the stock of natural resources which has a negative impact on production, immediately or at a later stage. A major weakness in such an analysis is the lack of feedback mechanisms through the economy since prices are set exogenously.

A more general approach is a two-step bio-economic modelling. Heterogeneous farm households first choose the production technique and then the use of input on a given plot of land in order to maximise profits with exogenous prices (Barbier, 1998; Ruben et al., 1998; Barbier and Bergeron, 1999). Changes in the macroeconomic policy affect costs and income and the farmers adapt to the new situation. Market equilibrium for final products is reached on a regional level through model iterations, but the effect on international trade, labour and the capital market is not included.

A full macroeconomic equilibrium model is needed in order to include all the repercussions through the economy from an initial policy change. Microeconomic details like differentiation between farmers and production techniques are often left out in order to solve macroeconomic complexity. Early attempts to integrate ecology in Computable General Equilibrium (CGE) models made environmental degradation (emissions, land clearing etc.) proportional to economic variables like production and input use. Nature itself had no impact on the economic productivity (Unemo, 1993; Coxhead and Jayasuriya, 1995; Persson and Munasinghe, 1995; Coxhead and Shively, 1996; Glomsrød et al., 1997; Coxhead, 2000). One-way effects in the opposite direction from environmental degradation on the economy is another possibility. Alfsen et al. (1996) used estimates of the annual reduction in soil nutrients for different crops on Nicaraguan land as exogenous inputs to the CGE production functions. When production is affected, so are equilibrium prices and the allocation of resources in the economy. Comparisons of GDP levels, with and without nature's productivity effect, reveal the equilibrium cost of soil degradation.

This paper integrates the two single-direction approaches by creating a CGE model where production decisions in agriculture affect soil productivity, and vice versa. Such two-way linkages between ecology and economy in macroeconomic models have, to some degree, been applied in models where economic activity causes pollution, entailing corrosion on real capital and sick-leaves with a negative impact on economic production. Alfsen et al. (1997) and Grepperud and Wiig (1999) have made similar ecology-economy linkages through agricultural production in CGE models. The technical contribution of this study is the inclusion of the soil degradation model in the production functions as a time-dependent Hicks' neutral productivity coefficient. The micro-foundation is a Tropical Soil Productivity Calculator (TSPC) developed by Aune and Lal (1995) which, among other limiting factors to plant growth, models the nitrogen cycle of the soil. There is a positive feedback from increased production on soil conservation as the stock of the natural resource increases in contrast to the earlier optimisation literature (Copeland, 1994; Barret, 1997 etc.) which assumes the opposite. More inputs on a given piece of land strengthens the growth and leads to more robust plants. A more powerful and dense foliage impedes heavy rains from falling directly 
on the ground, and hence, reduces soil erosion. A strong root system also prevents soils from being carried away by wind and surface water runoffs. More nitrogen is recycled in the form of increased volumes of residuals from roots and stover in the following years. As the growth of the plant is usually limited by the nutrients that are lacking the most, we just include the nitrogen part of the TSPC in the Tanzanian case. Dynamic changes in the content of other nutrients, water infiltration rates, water-holding capacity, soil biota and soil depth (Pimentel et al., 1995) are left out as productivity factors in their own right. Meanwhile, they are implicitly included as long as they influence the nitrogen supply to the plants. A policy change like a reduction in fertiliser subsidies will thus lead to a reduction in soil nitrogen (economy on ecology) which is the source of reduced production in the following years (ecology on economy).

The bulk of the literature on soil models has been used in a West European and North American context, like Foltz (1995) or Vickner et al. (1998) who used soil models like the Erosion Productivity Impact Calculator (EPIC) developed by Williams et al. (1987) to assess environmental impact in the form of nitrate leaching from the choice of the economically optimal cropping system in the Midwest of the US. The impact on society is more important in the third world. Barbier (1998) included the EPIC in an economic setting for a village in Burkina Faso in order to describe the optimal migration pattern. Alfsen et al. (1997) measured the implication of greater openness on migration to the rain forests of Ghana, while Grepperud and Wiig (1999) assess the effect of staple food exports on the GDP for Tanzania.

The analysis in this paper contributes to the vast amount of literature on the economic consequences of market liberalisation aspects of the SAPs since it explicitly includes the special feature of soil degradation in the models. The SAP of Tanzania is introduced step by step in order to separate the different effects. Subsidies on fertilisers and pesticides are removed, the closure of marketing boards implies a reduction in implicit export taxes on cash crops, a devaluation influences the balance of payment, and a reduction in government expenditure affects aggregated savings and a cut in foreign transfers if a reduction in development aid is not replaced by private inflows of foreign capital. We find that the SAP has a positive impact on economic growth: the GDP is $9 \%$ higher in the final year compared to the baseline scenario, mostly due to higher producer prices in the agricultural sector. The effects on the environment are mixed. The use of agro-chemicals has decreased by nearly $50 \%$, but agricultural production still increases by nearly $20 \%$ since more land, labour and capital is applied. The SAP scenario, nevertheless, has just a minor impact on the natural soil productivity. This analysis shows that, when a plot of land is under continual farming, the constant rate of reduction in soil organic nitrogen is the most important factor, which determines the natural soil productivity. Different levels in the vegetation cover factor, depending endogenously on production per unit of land in the different steps to the full SAP scenario, seem to have little effect on the natural soil productivity. However, we find that the inclusion of endogenous soil degradation is significant for economic growth in Tanzania where agriculture constitutes a dominant share of the economy. The GDP level obtained using an integrated model version is more than 5\% lower after 10 years in the baseline policy scenario compared to that when using a conventional CGE model with constant soil productivity.

This paper is organised as follows: Section 2 describes the historical and political development leading to the implementation of the SAP towards the end of the 1980s. In Section 3, the CGE model is presented, and the soil model follows in Section 4. The state of the economy in the base year 1990, which is used to calibrate the model, is described in Section 5, while the simulations of different economic scenarios are presented in Section 6. Conclusions follow in Section $7 .^{2}$

\section{Economic transition}

At the time of gaining independence in 1961, Tanzania was one of the poorest countries in the

\footnotetext{
${ }^{2}$ Appendix A contains tables summarising the main results of the simulations. Appendices B-F present lists of equations, variables and parameters, the base year social accounting matrix (or input-output matrix), and finally, a description of the soil module and its implementation in the CGE core model.
} 
world, mainly dependent on subsistence agriculture (World Bank, 1991). The Arusha Declaration of 1967 initiated a period of pervasive state control over the economy and development under the slogan of 'African Socialism'. Economic policies comprised price controls, a huge public sector, parastatal enterprises with soft budget constraints, rigid discriminative exchange rates for foreign currencies, high import tariffs to protect the national industry against external competition and deficits in the governmental budget and the foreign account. However, small-scale trade and production, farming of basic foods included, remained in private hands as the agricultural collectivisation programme failed. Transportation and distribution systems, however, were controlled by the state.

This more or less centrally controlled economy was shaken by the oil price shock in 1979-1980 and the war with Uganda, which led to payment problems for import commodities. A deep recession hit the economy in the beginning of the 1980s. The government introduced the National Agricultural Policy (NAP) plan in 1982, which encouraged private investment in large-scale farming (Eriksson, 1991). The World Bank and IMF supported the government in launching the Economic Recovery Programme (ERP) in 1986. Step by step, the Tanzanian economy was supposed to change into a modern capitalistic economy upon introduction of the SAP.

An important task was to obtain 'macroeconomic stabilisation', which implied scaling down the state sector to balance the public budget, dissolving parastatal enterprises and devaluating the Tanzanian Shilling. Another important component of the structural adjustment was to 'get the prices right'. This meant removing subsidies and price controls, dissolving state monopolies and letting private competition and market forces match supply and demand.

Of particular interest to the agricultural sector were the removal of subsidies on agro-chemicals and the dissolution of governmental price controls, which had implied a pan-territorial pricing system. This was meant to increase farmgate product prices, encouraging farmers to increase their efforts in order to raise the output. Export-crop producers were expected to gain from the devaluation of the local currency and to become a motor behind export-led growth.

\section{The economic model}

The complete model is composed of 342 equations, of which 66 constitute the soil model and 276 describe economic features in the CGE model. It covers 20 production sectors (of which 11 are agricultural sectors) and 22 goods. The Social Accounting Matrix (SAM) for Tanzania for 1990 (Balsvik and Brendemoen, 1994) is used to calibrate the parameters in the CGE model.

The model assumes that the producers maximise profits in a near-perfect market economy where the producers exercise no market power. The Cobb-Douglas production functions are homogeneous, of Degree 1, which implies that marginal cost equals average cost. The variable input factors are capital, labour, land, pesticides and fertilisers, while cross-deliveries of goods from other industries are proportional to the total output. The productivity parameter of each variable input is calibrated to be equal to the input share of the total variable cost.

Consumers receive all of the income from the production factors of labour, real capital and land. After paying income taxes, a certain share is set aside as private savings and the rest is spent on consumption. With this constraint on total consumption expenditure, a consumption bundle is chosen so as to maximise a utility function of the Stone-Geary type. The result is the Linear Expenditure System (LES), where the consumer will always consume a minimum amount of each good, independent of price changes, and where the surplus money from the expenditure budget is spent with constant coefficients for each good. These coefficients are calibrated from the SAM, while minimum consumption is estimated from other sources.

The investment market is the main structural feature of the model. Total savings, i.e. private savings by consumers plus government savings, which are the difference between the government net tax income and the government spending, equal total investment, consisting of gross real investment, change in inventories and financial investment in foreign countries. The last two terms are exogenous and leave gross real investment as the residual factor when total savings are set at the macro level. The amount available for real capital expenditure is then distributed amongst the different industries with a constant coefficient that is equal to the distribution of real investments in the base year. 
Thus, there is no profit maximisation behind the investment decisions since the industries do not have to pay for them directly. The result is an uneven marginal productivity of capital for the different industries. All government savings are classified as investments in private industries, and all government expenditure is defined as consumption.

The actual demand for goods is an aggregate of domestically produced and imported goods described by a Constant Elasticity of Substitution (CES) function. The purchaser seeks to minimise costs for a given level of total demand. Production in each industry is similarly divided between sale on the home market and exports using a Constant Elasticity of Transformation (CET) aggregate. The producers will choose the optimal allocation to maximise the profit from a certain production level. The substitution elasticities in both types of functions are 'guesstimates' based on experiences and estimates from other countries, while the other parameters in the functions are calibrated to the SAM of 1990.

Technically, in an equilibrium model where all endogenous variables are determined simultaneously, any exogenous variable 'closes' the model (i.e. changing the value of an exogenous variable changes the resulting equilibrium values of the endogenous variables). In this model, foreign transfers (negative financial savings abroad) comprise one such important exogenous variable. Aid and investments by foreign and multinational institutions are not in the control of Tanzanians. The transfer from abroad is made in foreign currency and equals the foreign trade balance. This condition is formally excluded from the model as the dependent equation, due to Walras's law which postulates that the last market must be in equilibrium if supply equals demand in the other markets.

In our CGE model, we assume that all modelled markets are in equilibrium, which seems rather unrealistic for a country like Tanzania in the base year 1990, when parts of the command structure in the economy persisted. Either surplus demand or surplus supply is likely to arise when prices are set by an institution. In Tanzania, most farmers received rather low prices for their goods. In return, they received subsidies for rationed input factors like fertiliser and pesticides.

Parameters in the Cobb-Douglas production functions are calibrated to equal the cost shares of each input factor in the base year 1990. Agro-chemicals are imported, and since the state had limited resources of foreign exchange, this leads to the rationing of agro-chemicals. This rationing results in downward biased parameters for the input when we use the official prices. Hence, the productivity parameters for fertiliser and pesticides in our model are probably too low compared to the productivity found in field experiments. The productivity parameters for labour, capital and land are, in turn, likely to be upward biased.

Another problem in the modelling of the agricultural sector in third world countries is the high proportion of subsistence agriculture used where no trade is feasible. However, the aim of this exercise is to examine how the Tanzanian economy will develop if the country accomplishes the transition to a modern market economy. It is then natural to employ a market-based economic model with few structural features. The introduction of various actions in the SAP has, in fact, made the country more of a market economy. Studies indicate that the farmers respond to price signals, both regarding crop selection and total agricultural supply (Eriksson, 1993).

The SAM of 1990 which is used to calibrate the parameters of the model had certain features that we have chosen to change for the following years. Most important is probably the change in the private savings rate from $-0.4 \%$ in 1990 to $5 \%$ for the simulation period.

Capital accumulation and technological change are the driving forces in this model. Technological change is Hicks-neutral and set to $1 \%$ per annum (p.a.) for all non-agricultural industries and $0.5 \%$ p.a. for agricultural industries except coffee, which is assumed to have a rate of technological change of $1 \%$ p.a.

\section{The soil model}

The 66 equations in the integrated soil model describe the soil degradation process, which happens through soil mining and soil erosion. It is based on the TSPC developed by Aune and Lal (1995). Comparison with two different sets of experimental data tested the predictability of the soil model. The models were tested against data collected from the fertiliser experiment over 17 years from Kasama in north- 
ern Zambia. This site has agro-ecological conditions similar to those found in the Southern Highlands of Tanzania. The model was able to predict $75 \%$ $\left(r^{2}=0.75\right)$ of the changes in yield over the years and across three fertiliser treatments (Aune and Massawe, 1998). The model's ability to predict the effect of soil erosion was tested by comparing with data obtained in experiments at seven sites in Tanzania where the soil within each site was classified in different erosion classes according to soil depth. The model predicted that the decrease in yield per centimetre removal of soil was within the range of the observed data (Aune et al., 1998).

Only the nitrogen cycle is integrated into the soil mining process. However, nitrogen limitation to plant growth is the most important factor for productivity decrease in Tanzania, and thus, the major soil degradation effects are captured by our soil model. Mineralised nitrogen to the plants is available from three sources: (i) atmospheric nitrogen from rainwater; (ii) external supply from chemical fertilisers and (iii) nitrogen recycling from the residues of roots and stover. When a crop is harvested, parts of the plant are taken away from the field. The residues are left in the soil to decompose. In this process, the available nitrogen is released through two different processes. One part is mineralised directly, but it takes 2 years before the process starts, and then it extends over a 3 -year period before all the nitrogen has been released. The second part of the nitrogen content in roots and stover is absorbed in the stock of soil organic nitrogen in the humus layer in the following year, and this stock releases a certain percentage of mineralised nitrogen each year. But the stock of soil organic nitrogen is a part of the soil organic matter in the $20 \mathrm{~cm}$ layer of topsoil, which decreases every year because of soil erosion. Soil erosion, in turn, depends on the yield per hectare. More and bigger plants have a denser leaf canopy, which reduces the kinetic energy of rainfall, so that the drops hit the ground with less intensity. Big plants have more roots and are able to keep the soil from loosening when the raindrops hit the ground. A greater number of roots is translated into a higher capability for recovering lost soil eroded from other plots of land, (see the equations in Appendix B and the illustration in Appendix F). The technical integration of the nitrogen cycle into the production function is explained in Appendix G. A major complication when integrating the economic and soil models is the construction of a common variable for the use of land. Land use in hectares for each crop is taken from the official agricultural statistics of Tanzania. However, our model's unit of measure is 'homogeneous' land and not hectares. If farmers move the agricultural frontier towards less fertile land, they need more hectares of land to produce the same amount of crop.

$\mathrm{pkl} \times \mathrm{KL}=$ lan $\times$ PRFT

In the model, Eq. (1) determines the use of land (KL). We assume that a certain part (lan\%) of the gross profits (PRFT) in the agricultural industries is in fact land rent and the rest is a return to real capital. The land rent differs among crops, reflecting different soil qualities. Even though there is a lot of uncultivated land in Tanzania, land scarcity in some regions, for instance Kilimanjaro, results in high resource rents in industries like coffee. Lack of roads, the national parks and tse-tse flies reduce the available land in Tanzania to $30 \%$ of the total arable land (World Bank, 1994). Due to this scarcity of land suitable for coffee production, we have chosen to model this industry with a constant amount of homogeneous land. We have done the same for tobacco since production is limited by the restricted supply of firewood to cure tobacco leaves. Consequently, the resource rent (pkl) on each unit of homogeneous land is endogenous in these two sectors, while the use of land is endogenous and the land rent exogenous in the other nine agricultural industries of Tanzania.

The soil model is a separate module linked to the economic model through the natural soil productivity variable (bbhat) for each crop. The soil model is recursive in time, where bbhat is a function of the yield per unit land $(X / \mathrm{KL})$ from the economic model in earlier years, through the soil-nitrogen variables. The model is not simultaneous in the sense that soil productivity, economic variables and soil variables are all endogenous variables in the same year. The status of the soil variables in 1 year $(t)$ determines the value of soil productivity the next year $(t+1)$, which gives rise to the economic solution for that year $(t+1)$. The economic variables from that year are the input to the soil variables in the same year and in the following years, thus determining the soil productivity variables for the next year. 


\section{The Tanzanian economy in 1990}

Our basis for calibration of the economic model is the SAM from the original base year, 1990 (Balsvik and Brendemoen, 1994), constructed from official statistics and merged with other sources of information to make a consistent accounting system. The agricultural industries are important contributors to the GDP in the economy, making up $24.0 \%$ of the total GDP at market prices which is high compared to other industrialised countries but far below the official numbers. ${ }^{3}$ If we include the livestock industry with $7.3 \%$ of the GDP as an agricultural industry, the relative importance increases to $33.4 \%$ of the GDP. The other sectors in the economy are forestry (3.1\%), food $(7.2 \%)$, textiles $(3.6 \%)$, other manufacturing industries (14\%), construction (5.6\%), electricity (1\%) transport $(7.7 \%)$, other private services $(17.4 \%)$ and governmental sector $(7.3 \%)$.

The level of mechanisation in production is rather low in Tanzania. Only a few agricultural sectors (coffee, tea, tobacco, cashew and maize) use any machinery at all. Their share of the total gross investment was only $1.6 \%$. The capital-intensive sectors were transport (44\%), which mostly uses cars and other machinery, and other private services (32\%) with buildings and some machinery. The sectors' share of total gross investment is kept constant for all years and steps towards the full SAP scenario as explained in Section 3.

An important component in the real capital stock is transport equipment and machinery of different kinds. Most of this is imported and other manufactured goods constitute $82 \%$ of all imports measured in CIF values. On the other hand, agricultural products constitute a large share of the exports, with $34 \%$ of the total exports in FOB prices. Other important exports are transport services $(19.7 \%)$, which are mostly services to landlocked neighbouring countries, and other private services (19\%) which include tourism.

Value added from the principal production factors of labour, real capital and land equals the GDP at market prices and less indirect taxes. The land rent is the resource rent reflecting land scarcity, wages are

\footnotetext{
${ }^{3}$ National Accounts in Tanzania are under major revision to capture the impact of a reorientation towards deregulation and privatisation (World Bank, 1996). The official figures probably underestimate the national income level.
}

rewards for labour efforts and profits are the surplus from sales, i.e. reward for the stock of real capital employed in production. Wages constitute $68 \%$ of the total value added (governmental employees included), $28 \%$ profits and $4 \%$ land rent.

Agriculture is the main source of labour income in Tanzania, generating 35\% of all wage income but only $1 \%$ of the profits. Real capital-intensive industries like transport and electricity have limited expenditure on wages, while livestock, forestry, construction and other private services are labour-intensive.

\section{Results of the simulations}

How does the SAP affect economic growth and soil degradation? Baseline scenario A is the business as usual scenario with the economy-ecology integrated model. The policy changes of the SAP are then introduced stepwise, one on top of the other, until the full package is reached in Scenario F. We apply the average annual growth rate for a given variable in the different steps to compare the impact of each policy change or we compare the absolute level in the final year. Real values are measured in constant 1990 prices.

\subsection{Economic features}

The average annual growth rate of the real GDP in baseline scenario A is $1.8 \%$ p.a., where especially non-agricultural industries like transport (5.5\% p.a.), electricity (3.0\% p.a.) and other forms of manufacture (2.6\% p.a.) have large growth rates. The growth in real GDP for the agricultural industries was just $0.6 \%$ p.a., where the cash crops tobacco (3.3\% p.a.), coffee ( $2.4 \%$ p.a.) and cashews (1.6\% p.a.) contributed the most.

There are three important factors behind this economic growth. The assumed Hicks neutral technological change in the production functions is set to $1 \%$ p.a. in the industrial sectors and $0.5 \%$ p.a. in the agricultural sectors, except for coffee where productivity increases by $1 \%$. The agricultural sectors are, on the other hand, exposed to soil degradation, and this Hicks neutral productivity coefficient stretches from being constant for cashew nuts to a reduction of $2.7 \%$ p.a. on an average for tea. Then, the stock of real capital (a variable input factor in production) increases by $4.2 \%$ p.a. due to a positive net investment rate in all sectors. 


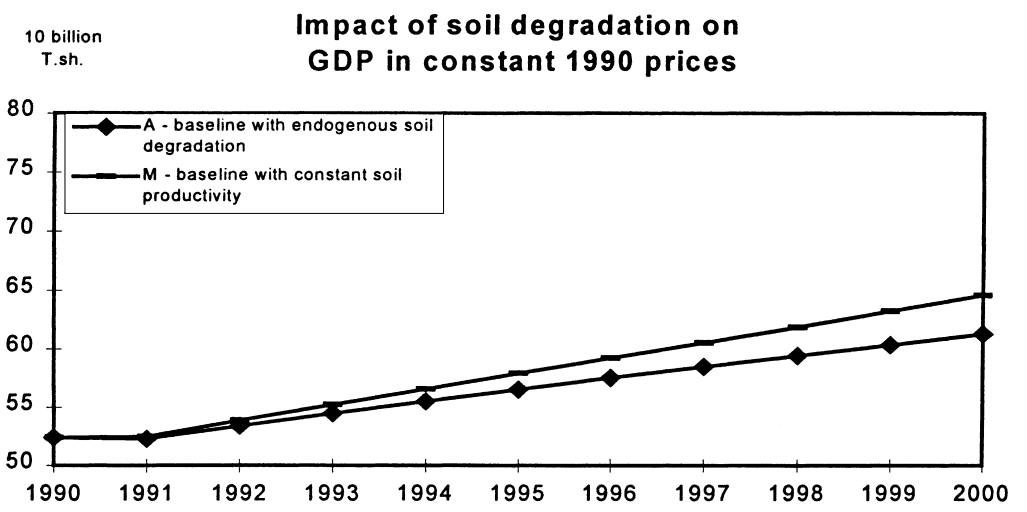

Technological progress implies that lesser variable input factors are needed to produce the same amount of output, reducing the marginal cost of production of goods. Higher volumes will be produced, and the price will go down in order to let demand equal supply. Then, the production sectors need more inputs of goods, and there is a secondary demand effect working through the economy. Higher real GDP and increased net disposable income for the consumers are the results.

Productivity reduction due to soil degradation will reduce these expansionary effects in the agricultural sectors. Total Hicks's neutral productivity (technological progress and soil degradation) is reduced even for tea, maize and other crops, leading to higher marginal cost in production over time. In the other agricultural sectors, technological progress overshadows the soil degradation effect. It is profitable for the sectors to use relatively more of input factors to compensate for reduced natural productivity. The total effect might even be higher production volumes since the overall size of the economy increases. An example is maize production, where the use of labour increases by $1.9 \%$ p.a., fertilisers by $1.7 \%$ p.a. and land by $1.7 \%$ p.a., as the net Hicks's neutral productivity falls by $1.6 \%$ p.a. (a positive technological change of $0.5 \%$ p.a. and a negative change in the natural soil productivity due to soil degradation by $2.1 \%$ p.a.). The total effect is a small increase of $0.2 \%$ p.a. in the volumes produced.

The effect of the usage of more inputs to replace the natural soil productivity is even more visible if we look at a comparable baseline scenario without the soil degradation effect (M). Then, the use of labour in the maize sector is $15 \%$ lower in the year 2000 compared to the baseline scenario with the soil degradation process (A), even though the production volume is $5 \%$ higher. When markets adjust prices upward (the producer prices in the agricultural sectors are $13 \%$ higher in Scenario A), the negative effect of soil degradation on the GDP is counteracted. The cash crop producers are most affected by reduction in soil productivity since world market prices are constant and independent of the volumes exported from this country. And the total effect of soil degradation on economic development is painful for the Tanzanian society. The annual growth rate in real GDP falls by $0.5 \%$, from $2.3 \%$ p.a. in Scenario $M$ without soil degradation to $1.8 \%$ p.a. in Scenario A with soil degradation. The resulting GDP level in the year 2000 is 5.2\% lower in A than in M, due to the soil degradation process.

There is a positive investment rate in both baseline scenarios. In baseline scenario A, real capital increases by $4.2 \%$ p.a. This increases the marginal productivity of the other input factors and reduces the marginal cost of production. The result is more use of inputs and higher production volumes, leading to higher economic growth. Since total production increases more in Scenario M when there is no negative soil productivity effect, there is even more of investment in the economy. The difference in net investment is still not very important as the capital stock is just $0.1 \%$ higher in Scenario M in the year 2000 than in Scenario A. The main parts of real GDP growth in baseline scenario A are consumption (1.4\% p.a.) and gross real investment ( $1.5 \%$ p.a.). Governmental demand is an exogenous variable and is held constant. Gross foreign trade increases, with growth in exports of $3.5 \%$ p.a. and imports of $1.1 \%$ p.a. The resulting deficit on foreign trade is constant by assumption. 
Subsidies on agro-chemicals are further removed in Step B from the baseline scenario with the endogenous soil degradation process. Fertiliser and pesticide subsidies are then gradually reduced from $60 \%$ (fertilisers) and 50\% (pesticides) in 1990, to 0 in 1995. Surprisingly, the GDP level in constant prices falls by $2.0 \%$ compared to baseline scenario $\mathrm{A}$ in the year 2000. The reduction in subsidies leads to a proportional increase in purchaser prices of inputs since all agro-chemicals are imported at constant world market prices. The negative effect is large; fertiliser use falls by $61 \%$ and pesticide use by $70 \%$ compared to baseline scenario A. Farmers substitute with labour and land. But the marginal cost of production has increased and the produced volume will fall. This is especially important for the cash crop producers since export prices are constant. These sectors are also hardest hit by the removal of subsidies because they are the most important purchasers of agro-chemicals. The result is a reduction in agricultural exports in constant 1990 prices of $33 \%$ in the year 2000 compared to baseline scenario A. Since the activity level falls, the need for inputs from other sectors is reduced too, thus leading to a general contraction in the economy.

The removal of subsidies partially increases net governmental revenues. But other tax income sources are adversely affected. The implicit export tax on agricultural products (explained in the next paragraph) is high and the reduction in tax income from this source due to reduced agricultural exports nearly outweighs the savings of less of subsidies. If we include the reduction in other tax sources due to lower economic activity, net governmental revenues in the year 2000 is $1.1 \%$ lower than in Scenario A. The subsidies on agro-chemicals have, in fact, corrected this efficiency loss of heavy taxation (Harberger triangle) by increasing the volume produced, leading to higher economic growth. Since both governmental revenues and private savings decrease, expenditure on real investment is $0.6 \%$ lower in the year 2000 compared to baseline scenario A and the stock of real capital is reduced.

Further refinement in Step C is a reduction in the implicit export tax on cash crops, which is another way to reduce the efficiency loss. It is important to notice the rationale behind this policy change. In the base year 1990, parastatal marketing boards bought the crops directly from the farmers in the countryside at given prices in Tanzanian shillings and sold them for dollars in the world market. The difference has been registered as a tax on export crops in our model. The implicit tax on agricultural exports falls from 87.5 to $50 \%$ in the first year, illustrating a move from governmental to private marketing services. This shifts the cost burden from the public to the private sector since the farmers have to buy the marketing service from private companies. This is not included in the model as the input-output coefficients are held constant. It is, however, expected that a marketing reform will initiate a significant rise in marketing efficiency and that the increase in farmers' cost might be much smaller than the reduction in the implicit export tax. The annual growth in real GDP in constant prices is now $2.1 \%$ and the result is a $3.2 \%$ higher level in the year 2000. The GDP is even higher than in baseline scenario A, as illustrated below.

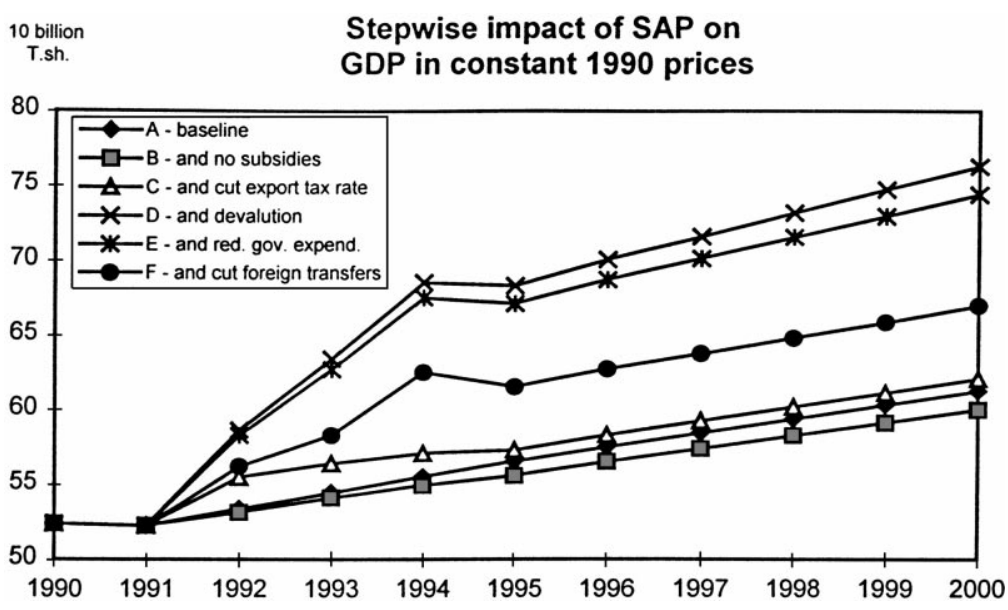


This increased GDP level is mainly due to the rise of $23.8 \%$ in real agricultural exports compared to Step B in the year 2000, which is a result of the increase in export producer prices when the implicit export taxes are reduced. Since there are no subsidies in this scenario, the farmers increase production by increasing their use of the variable input factors like labour, land, fertilisers and pesticides at the same rate. Rising private income leads to a general demand effect in the economy, and production increases in all sectors.

The export volume effect overshadows the cut in the implicit export tax rate, increasing the total implicit export tax income by $15.6 \%$ compared to the preceding scenario, Scenario B. This positive effect shows that the taxation rate is set high (e.g. negative side of the Laffer curve). Higher economic growth also leads to higher tax income from other sources, and the total effect on governmental revenues is an increase of $4.5 \%$. This entails higher governmental savings, greater expenditure on real investment and a $1.0 \%$ higher capital stock in the year 2000 in this scenario compared to the preceding scenario, Scenario B.

The next step, Step D, is a devaluation of the local currency, Tanzanian shilling, that leads to an increase in producer prices in the export-oriented sectors. In this scenario, there is a $10 \%$ nominal devaluation in each of the years 1992, 1993 and 1994, in addition to the policy changes carried out in the preceding steps. The average growth in real GDP now reaches a respectable $4.2 \%$ p.a., which results in a $23.2 \%$ higher GDP level in 2000 than in Step C. The main partial effect is an increase in total exports in constant 1990 prices by $42.6 \%$ due to a total increase of $33.1 \%$ in producer prices for exported goods. There is a scale effect in production, which implies more use of all endogenous input factors like labour (up 34.6\%), fertilisers (up 6.7\%), pesticides (up 31.1\%) and land (up $19.7 \%$ ). But the rise in production in the export industries is also due to a substitution effect since the relative producer price between the export and domestic markets increases, and producers prefer to sell their goods in the world market instead. But this effect is counteracted by the demand side of the home market in two ways. When supply to the home market decreases, the prices increase and the relative change is not that large anymore. Devaluation of the currency has also made imports more expensive, and purchasers turn their demand towards the home-produced goods, giving rise to an extra demand effect. The result is a price increase for domestically produced goods of $10.7 \%$ compared to the preceding step, Step C, and total production increases.

When total production increases, more money is paid in wages and profits. This entails extra private savings in the year 2000 (36.0\% higher than Step C) and more of governmental savings (up 78.1\%), due to higher governmental tax revenues. The extra savings spill over to investment expenditure and the stock of real capital is $7.9 \%$ higher in the year 2000. This increases the marginal productivity of the other input factors, reduces marginal cost and leads to higher production. The partial effects of a devaluation are greater exports and lesser imports, since the balance of the current account is set exogenously.

A cut in governmental expenditure is made in Step E of the SAP package. Both governmental consumption and employment are reduced by $3 \%$ p.a. (26\% reduction in level by the year 2000). The average real GDP growth rate is now $3.9 \%$ p.a., which leads to a reduction in the GDP level by the year 2000 of $3.1 \%$ compared to Step D. The first-order effect of a reduction in government employment is a reduction in the GDP by the same amount. The reduction in private wage income entails a negative demand effect on the economy in addition to the equivalent reduction in private savings. But the reduction of governmental demand for goods also leads to lesser production and entails a contraction in the economy. The result is a reduction in governmental revenues of $2.8 \%$ compared to the preceding scenario, but governmental savings increase by $13.4 \%$ because of the reduction in expenditure. The net effect of more of governmental but less of private savings is positive, and the stock of real capital is $1.2 \%$ higher in the year 2000 than in the preceding step, Step D. This should lead to higher production in the economy. However, the marginal productivity of real capital differs a lot between the industries, from 0.3 in the food processing industry to 0.0005 in the electricity producing industry. Since most of the investment is distributed amongst sectors with low marginal productivity of real capital, the increase in the stock of real capital contributes with little extra production to the GDP compared to the negative demand effects.

The last step, Step F, is a cut in foreign transfers and this scenario now includes all assumed SAP 
policy changes. Foreign transfers (or foreign account balance) are one of the important exogenous variables closing the model. In the long run, an important goal for the SAP is to reduce the African countries' dependence on foreign aid. In this scenario, we have reduced the transfers by $9 \%$ from 1991 to 1992 and by $9 \%$ from 1992 to 1993 (the total reduction is $17.2 \%$ ). Then, the average growth in real GDP is reduced to $2.8 \%$ p.a., which results in a $9.4 \%$ higher GDP level in the year 2000 than in the case of baseline scenario A, but a $12.1 \%$ lower GDP in the preceding step, Step E. The reduction in foreign transfers has to increase the relative importance of exports compared to imports, which is reached by a general contraction in the economy. Imports are down by $15.2 \%$, while exports are reduced by $11.5 \%$. This originates from the first-order effect of a reduction in foreign transfers which is a corresponding reduction in real investment expenditure, since we assume that none of these transfers is spent on consumption, either by the private or the governmental sector. Hence, the total effect on real capital accumulation is a reduction in the stock by $9.1 \%$ in the year 2000 compared to the preceding scenario, and this entails a significant downturn in economic growth. The total effect of all SAP policy changes in this scenario, Scenario $\mathrm{F}$, is positive compared to the baseline scenario without any changes (A). The GDP in constant 1990 prices is higher, and the composition is turned more towards agricultural production, which is $17.2 \%$ higher than in baseline scenario A. The agricultural share of GDP (excluding livestock production) in the year 2000 increased from $20.8 \%$ of the GDP in baseline scenario A to $24.5 \%$ in this full SAP scenario $(\mathrm{F})$.

We assume constant nominal wages and elastic labour supply (Keynsian labour market) which implies increasing production costs as the general price level decreasing in this model where the money market is not included. If we change to constant real wage in the full SAP scenario, the real GDP increases by $3.5 \%$ p.a., which entails a $14.1 \%$ higher level in the year 2000 than in Scenario F.

\subsection{Soil features}

Natural soil productivity, soil depth and use of land are three important environmental variables. The fall in natural soil productivity differs a lot between crops, from constant productivity for cashews, which is not dependent on the nitrogen content in the soil, to an average annual decline of $2.8 \%$ for tea, $2.1 \%$ for maize and $1.9 \%$ for other crops in baseline scenario A. This loss in soil productivity is partly compensated by technological progress, set to increase by $0.5 \%$ p.a. for all crops except coffee with a rise of $1.0 \%$ a year. Soil productivity (bbhat) is determined in the soil model and is dependent on three main components: the constant rate of mineralisation from the stock of soil organic nitrogen (NS), directly mineralised nitrogen from the residual roots and stover (NRR) and nitrogen from the atmospheric nitrogen deposition (nas).

Theoretically, the level of production per unit of land $(X / \mathrm{KL})$ influences the available nitrogen both through NS and NRR, but our results show that the latter effect is small compared to the mineralisation process from the initial NS stock. The natural soil productivity variable (bbhat) declines more or less at the same rate for all SAP steps $(\mathrm{A}-\mathrm{F})$. The exceptions are cotton, which has a $0.1 \%$ lower bbhat level in Scenario F in the year 2000 than in A, coffee with a $0.5 \%$ higher bbhat level, tobacco with a $0.04 \%$ higher bbhat level and maize with a $0.6 \%$ lower bbhat level. For the other agricultural products, there is no difference at all. We will illustrate the effect of the different scenarios on various variables for the most important crop viz. maize.

Maize, deviation in the level of variable value in the year 2000 from Scenario A (\%)

\begin{tabular}{|c|c|c|c|c|c|c|}
\hline A & B & $\mathrm{C}$ & D & $\mathrm{E}$ & $\mathrm{F}$ & M \\
\hline bbhat & -0.43 & -0.43 & -0.59 & -0.59 & -0.59 & 23.23 \\
\hline$D$ & 0.00 & 0.00 & 0.00 & 0.00 & 0.00 & n.a. \\
\hline NS & -0.13 & -0.13 & -0.17 & -0.17 & -0.17 & n.a. \\
\hline NR & -0.92 & -0.93 & -1.24 & -1.22 & -1.25 & n.a. \\
\hline NRR & -5.40 & -5.40 & -7.08 & -6.97 & -7.26 & n.a. \\
\hline $\mathrm{NE}$ & 0.59 & 0.59 & 0.76 & 0.75 & 0.78 & n.a. \\
\hline KL & 3.96 & 5.18 & 16.46 & 14.96 & 11.28 & -15.85 \\
\hline$u$ & -5.40 & -5.40 & -7.08 & -6.97 & -7.27 & 24.22 \\
\hline
\end{tabular}

Crop intensity $(u)$ is the production yield from one unit of homogeneous land (KL) and is the only factor influencing the soil variables of the model. The 
removal of subsidies in Scenario B entails less use of fertilisers and pesticides, reducing the crop intensity and equally reducing nitrogen from residuals in roots and stover (NRR) and increasing the amount of nitrogen lost due to soil erosion (NE). But the level of soil organic nitrogen (NS) only falls by $0.13 \%$ in the year 2000. Since NS constitutes $83.2 \%$ of all mineralised nitrogen in 1990, the total amount of nitrogen from natural sources (NR) is only $0.9 \%$ lesser in the year 2000 than in the baseline scenario. The elasticity of the natural soil productivity parameter with respect to NR is less than 1, and the resulting reduction in bbhat is $0.43 \%$ compared to the baseline scenario. This has a minimal effect compared to the scale of reduction in the use of fertilisers $(61.8 \%)$ and pesticides (70.0\%).

The export tax reduction and devaluation in the following scenarios have the effect of expanding production. But the use of land increases even more, leading to a decline in crop intensity, thereby reducing the natural soil productivity. However, this effect is rather small since the exogenous mineralisation rate of NS is the most important factor in determining the total amount of available nitrogen. The decline in soil productivity continues more or less independently of the crop intensity when a plot of land is first opened for continuous farming. The only way to keep the total productivity at the same level is to add more fertilisers. By the year 2000, this inexorable decline in the natural soil productivity results in a $18.7 \%$ reduction in the natural soil productivity in Scenario A compared to the same policy scenario where the natural soil productivity is exogenously held constant at the base year level (i.e. Scenario M is $23.2 \%$ above Scenario A). In the model, new land is assumed to be as productive as formerly cultivated land. In reality, land at the margin is likely to be less productive.

Soil depth is even less sensitive to the different policy scenarios. The removal of subsidies in Scenario B causes a $0.5 \%$ reduction of the soil depth for tobacco in the year 2000 compared to the baseline scenario. For the other crops, there is no difference between the scenarios. But the degradation process reduces the initial soil depth of $0.2 \mathrm{~m}$ to a range from $0.190 \mathrm{~m}$ for maize and sorghum (i.e. 5\% reduction) to $0.199 \mathrm{~m}$ for rice (i.e. $0.5 \%$ reduction) in the year 2000. This small erosion effect is also due to the short time period of 10 years, and the cumulative effect of the problem would probably have been more apparent if we had run the model over a greater number of years.

Total use of land is another environmental aspect. In this model, we use the variable unit of homogeneous land which is linked to the amount of profit in each agricultural industry. The initial number of hectares in one unit of homogeneous land differs among crops in the initial year 1990, and the number of hectares per unit of homogeneous land increases when productivity declines. We do not have any measure for how much more land in physical terms is needed to meet the demand. In order to summarise land use for all crops, we have chosen to use a fixed coefficient of hectares per unit of homogeneous land over time, and in this way, we underestimate the total use of land for the variable 'total use of land', as presented in Appendix A. The result is that the total use of land is $3.5 \%$ higher in 2000 when subsidies are removed in Step B, in this way, substituting the relatively cheaper input of land for fertiliser. This is also due to a shift towards more land-intensive crops like cotton and cashews, while the production of food crops like cassava, rice and other crops is reduced due to the reduction of private income and food consumption. Thus, the use of land then increases in proportion to the increase in production, in steps C-F. $6.1 \%$ less land is used in the baseline scenario without the soil model (M) since there is less need for variable input factors to produce the same amount of food. In the total SAP scenario with constant real wages, gross production in the agricultural sectors increases by $19.7 \%$ compared to the SAP scenario with constant nominal wages, while the use of land decreases by $0.9 \%$, thereby illustrating the need for more labour in production as the nominal wage declines.

\section{Conclusions}

Tanzania, like most African countries, depends heavily on agricultural production, which constitutes a major part of the GDP and exports. In this model, we find that this situation may change as soil degradation undermines economic growth. In 10 years' time, the GDP level falls by more than $5 \%$ in our model with endogenous soil degradation, com- 
pared to a traditional CGE model with constant soil productivity.

The macroeconomic impact of structural adjustment policy measures like devaluation of the currency and a reduction in the implicit tax on export crops have positive impacts on the economy, mainly due to the sharp rise in agricultural exports. On the other hand, the cut in subsidies, governmental expenditure and foreign transfers seems to have a negative effect on economic growth. All measures in the SAP combined have a positive impact on economic growth in this model, and raise the GDP growth from 1.8 to $2.8 \%$ p.a.

\section{Acknowledgements}

We want to thank the Economy and Ecology Programme of the Norwegian Research Council for providing financial support to this project. Helpful comments during the process were received from Knut Alfsen, Ragnar Øygard and Sverre Grepperud.

\section{Appendix A. Main results}

Tables 1-7 summarise the main results of the simulations.

Table 1

Gross production (GP) and gross domestic product at constant 1990 market prices

\begin{tabular}{|c|c|c|c|c|c|}
\hline \multicolumn{2}{|c|}{ Scenario } & \multicolumn{2}{|c|}{ GP in constant 1990 prices } & \multicolumn{2}{|c|}{ GDP in constant 1990 prices } \\
\hline & & \multirow{2}{*}{$\begin{array}{l}\text { Growth (\% p.a.) }{ }^{\mathrm{a}} \\
2.04\end{array}$} & \multirow{2}{*}{$\begin{array}{c}\text { dev. } 2000(\%)^{\mathrm{b}} \\
0.00\end{array}$} & \multirow{2}{*}{$\begin{array}{l}\text { Growth (\% p.a.) } \\
1.77\end{array}$} & \multirow{2}{*}{$\frac{\text { dev. } 2000(\%)}{0.00}$} \\
\hline A & Baseline & & & & \\
\hline B & And no subsidies & 1.77 & -2.47 & 1.54 & -2.00 \\
\hline $\mathrm{C}$ & And implicit export tax reduction & 2.13 & 0.74 & 1.92 & 1.36 \\
\hline $\mathrm{D}$ & And devaluation & 4.55 & 25.28 & 4.21 & 24.58 \\
\hline $\mathrm{E}$ & $\begin{array}{l}\text { And reduction in Government } \\
\text { consumption }\end{array}$ & 4.39 & 23.47 & 3.93 & 21.50 \\
\hline $\mathrm{F}$ & And cut in foreign transfers & 3.10 & 10.02 & 2.76 & 9.36 \\
\hline M & Baseline w. constant soil productivity & 2.55 & 5.10 & 2.30 & 5.39 \\
\hline
\end{tabular}

a 'Growth' is the average annual growth rate in percent for the actual variable from 1991 to 2000.

b 'dev. 2000' is the deviation in percent for the variable value in the year 2000 in the actual scenario compared to baseline scenario A.

Table 2

Gross product and gross domestic product at constant 1990 market prices in the agricultural industries

\begin{tabular}{|c|c|c|c|c|c|}
\hline \multicolumn{2}{|c|}{ Scenario } & \multicolumn{2}{|c|}{ Agricultural GP in constant 1990 prices } & \multicolumn{2}{|c|}{ Agricultural GDP in constant 1990 prices } \\
\hline & & Growth (\% p.a.) & dev. $2000(\%)$ & Growth (\% p.a.) & dev. $2000(\%)$ \\
\hline A & Baseline & 0.62 & 0.00 & 0.58 & 0.00 \\
\hline B & And no subsidies & -0.36 & -8.46 & 0.11 & -4.16 \\
\hline $\mathrm{C}$ & And implicit export tax reduction & 0.42 & -1.77 & 0.86 & 2.56 \\
\hline D & And devaluation & 3.11 & 25.05 & 3.76 & 33.20 \\
\hline E & $\begin{array}{l}\text { And reduction in government } \\
\text { consumption }\end{array}$ & 2.97 & 23.55 & 3.61 & 31.38 \\
\hline $\mathrm{F}$ & And cut in foreign transfers & 2.37 & 17.06 & 2.94 & 23.71 \\
\hline M & Baseline w. constant soil productivity & 1.61 & 10.25 & 1.66 & 11.28 \\
\hline
\end{tabular}


Table 3

Use of variable production input factors in industries

\begin{tabular}{|c|c|c|c|c|c|c|c|}
\hline \multicolumn{2}{|c|}{ Scenario } & \multicolumn{2}{|c|}{ Total use of labour } & \multicolumn{2}{|c|}{ Total stock of capital } & & \\
\hline & & $\begin{array}{l}\text { Growth } \\
(\% \text { p.a. })\end{array}$ & $\begin{array}{l}\text { dev. } 2000 \\
(\%)\end{array}$ & $\begin{array}{l}\text { Growth } \\
\text { (\% p.a.) }\end{array}$ & $\begin{array}{l}\text { dev. } 2000 \\
(\%)\end{array}$ & & \\
\hline A & Baseline & 0.70 & 0.00 & 4.17 & 0.00 & & \\
\hline B & And no subsidies & 0.42 & -2.44 & 4.16 & -0.06 & & \\
\hline $\mathrm{C}$ & And implicit export tax reduction & 0.87 & 1.50 & 4.27 & 0.93 & & \\
\hline $\mathrm{D}$ & And devaluation & 4.12 & 36.06 & 5.11 & 8.84 & & \\
\hline $\mathrm{E}$ & $\begin{array}{l}\text { And reduction in government } \\
\text { consumption }\end{array}$ & 3.89 & 33.26 & 5.23 & 10.06 & & \\
\hline F & And cut in foreign transfers & 2.75 & 20.25 & 4.27 & 0.93 & & \\
\hline \multirow[t]{3}{*}{ M } & Baseline w. constant soil productivity & 0.78 & 0.77 & 4.24 & 0.62 & & \\
\hline & & \multicolumn{2}{|c|}{ Total use of fertilisers } & \multicolumn{2}{|c|}{ Total use of pesticides } & \multicolumn{2}{|c|}{ Total use of land (ha) } \\
\hline & & $\begin{array}{l}\text { Growth } \\
\text { (\% p.a.) }\end{array}$ & $\begin{array}{l}\text { dev. } 2000 \\
(\%)\end{array}$ & $\begin{array}{l}\text { Growth } \\
\text { (\% p.a.) }\end{array}$ & $\begin{array}{l}\text { dev. } 2000 \\
(\%)\end{array}$ & $\begin{array}{l}\text { Growth } \\
\text { (\% p.a.) }\end{array}$ & $\begin{array}{l}\text { dev. } 2000 \\
(\%)\end{array}$ \\
\hline A & Baseline & 1.96 & 0.00 & 2.09 & 0.00 & 0.99 & 0.00 \\
\hline B & And no subsidies & -8.72 & -61.77 & -11.26 & -69.93 & 1.37 & 3.45 \\
\hline $\mathrm{C}$ & And implicit export tax reduction & -7.42 & -57.02 & -5.07 & -47.52 & 1.66 & 6.20 \\
\hline $\mathrm{D}$ & And devaluation & -5.81 & -50.32 & 0.09 & -16.45 & 3.55 & 25.91 \\
\hline E & $\begin{array}{l}\text { And reduction in government } \\
\text { consumption }\end{array}$ & -5.76 & -50.11 & 0.04 & -16.88 & 3.39 & 24.10 \\
\hline $\mathrm{F}$ & And cut in foreign transfers & -6.15 & -51.84 & -0.33 & -19.57 & 2.83 & 17.98 \\
\hline M & Baseline w. constant soil productivity & 1.18 & -7.56 & 4.37 & 25.96 & 0.37 & -6.09 \\
\hline
\end{tabular}

Table 4

Units produced in the industries in the different scenarios

\begin{tabular}{|c|c|c|c|c|c|c|c|c|c|c|c|c|c|c|}
\hline \multirow[t]{2}{*}{$X^{\mathrm{a}}$} & \multicolumn{7}{|c|}{ Average growth 1991-2000 (\%) } & \multicolumn{7}{|c|}{ Level difference from baseline (A) in $2000(\%)$} \\
\hline & A & B & $\mathrm{C}$ & $\mathrm{D}$ & $\mathrm{E}$ & $\mathrm{F}$ & M & A & B & $\mathrm{C}$ & $\mathrm{D}$ & $\mathrm{E}$ & $\mathrm{F}$ & M \\
\hline COT & 1.43 & 0.77 & 2.09 & 6.81 & 6.50 & 5.31 & 2.43 & 0 & -6 & 6 & 62 & 58 & 42 & 10 \\
\hline $\mathrm{COF}$ & 2.42 & -10.42 & -0.95 & 6.18 & 6.22 & 6.11 & 5.42 & 0 & -69 & -26 & 40 & 41 & 39 & 36 \\
\hline TEA & 1.30 & 0.91 & 1.97 & 5.78 & 5.57 & 4.42 & 2.94 & 0 & -3 & 6 & 50 & 47 & 32 & 19 \\
\hline TOB & 3.29 & -0.50 & 3.72 & 14.21 & 14.37 & 14.27 & 4.44 & 0 & -29 & 4 & 167 & 171 & 168 & 12 \\
\hline CAH & 1.66 & -0.40 & 0.60 & 3.10 & 2.92 & 1.86 & 2.23 & 0 & -17 & -9 & 14 & 12 & 2 & 6 \\
\hline CAS & 0.01 & -0.02 & 0.02 & 0.47 & 0.40 & 0.23 & 0.12 & 0 & 0 & 0 & 4 & 4 & 2 & 1 \\
\hline MAI & 0.15 & -0.01 & 0.11 & 1.03 & 0.91 & 0.50 & 0.62 & 0 & -1 & 0 & 8 & 7 & 3 & 5 \\
\hline RIC & 0.62 & 0.48 & 0.65 & 2.15 & 1.99 & 1.39 & 0.98 & 0 & -1 & 0 & 15 & 13 & 7 & 4 \\
\hline SOR & 0.30 & 0.19 & 0.33 & 1.37 & 1.23 & 0.80 & 0.54 & 0 & -1 & 0 & 10 & 9 & 5 & 2 \\
\hline BEA & 0.14 & 0.05 & 0.15 & 0.92 & 0.82 & 0.49 & 0.32 & 0 & -1 & 0 & 7 & 6 & 3 & 2 \\
\hline OCC & 0.45 & 0.27 & 0.51 & 3.07 & 2.89 & 2.08 & 1.48 & 0 & -2 & 1 & 27 & 25 & 16 & 11 \\
\hline LIV & 1.18 & 0.88 & 1.29 & 4.48 & 4.08 & 2.83 & 1.71 & 0 & -3 & 1 & 35 & 30 & 16 & 5 \\
\hline FOR & 2.22 & 2.00 & 2.35 & 6.23 & 5.95 & 4.55 & 2.70 & 0 & -2 & 1 & 43 & 40 & 23 & 5 \\
\hline FOO & 2.01 & 1.70 & 2.09 & 4.63 & 4.40 & 3.18 & 2.73 & 0 & -3 & 1 & 27 & 24 & 11 & 7 \\
\hline TEX & 1.24 & 0.80 & 1.33 & 4.38 & 4.03 & 2.80 & 2.16 & 0 & -4 & 1 & 33 & 29 & 15 & 9 \\
\hline OMS & 2.60 & 2.50 & 2.74 & 5.14 & 5.25 & 3.70 & 2.93 & 0 & -1 & 1 & 26 & 27 & 10 & 3 \\
\hline $\mathrm{CON}$ & 2.14 & 1.98 & 2.30 & 5.07 & 5.07 & 3.46 & 2.52 & 0 & -1 & 1 & 30 & 30 & 13 & 4 \\
\hline ELE & 2.95 & 2.77 & 3.06 & 4.88 & 4.14 & 2.97 & 3.35 & 0 & -2 & 1 & 19 & 11 & 0 & 4 \\
\hline TRA & 5.52 & 5.45 & 5.61 & 7.29 & 7.31 & 6.34 & 5.68 & 0 & -1 & 1 & 17 & 18 & 8 & 2 \\
\hline OPS & 2.34 & 2.16 & 2.47 & 5.16 & 5.05 & 3.65 & 2.82 & 0 & -2 & 1 & 29 & 28 & 13 & 5 \\
\hline
\end{tabular}

${ }^{a}$ Short for crop names, see Appendix D. 
Table 5

Soil productivity parameter by agricultural industries in the different scenarios

\begin{tabular}{|c|c|c|c|c|c|c|c|c|c|c|c|c|c|c|}
\hline \multirow[t]{2}{*}{ bbhat } & \multicolumn{7}{|c|}{ Average growth 1991-2000 (\%) } & \multicolumn{7}{|c|}{ Level difference from baseline (A) in $2000(\%)$} \\
\hline & A & B & $\mathrm{C}$ & $\mathrm{D}$ & $\mathrm{E}$ & $\mathrm{F}$ & M & A & B & $\mathrm{C}$ & $\mathrm{D}$ & $\mathrm{E}$ & $\mathrm{F}$ & M \\
\hline OT & -0.29 & -0.30 & -0.30 & -0.30 & -0.30 & -0.30 & 0.00 & 0.00 & -0.08 & -0.08 & -0.12 & -0.12 & -0.12 & 3.01 \\
\hline $\mathrm{COF}$ & -0.65 & -0.74 & -0.68 & -0.59 & -0.59 & -0.59 & 0.00 & 0.00 & -0.83 & -0.29 & 0.54 & 0.54 & 0.54 & 6.84 \\
\hline TEA & -2.78 & -2.78 & -2.78 & -2.78 & -2.78 & -2.78 & 0.00 & 0.00 & 0.00 & 0.00 & 0.00 & 0.00 & 0.00 & 32.16 \\
\hline TOB & -0.26 & -0.26 & -0.26 & -0.25 & -0.25 & -0.25 & 0.00 & 0.00 & 0.00 & 0.00 & 0.04 & 0.04 & 0.04 & 2.66 \\
\hline $\mathrm{CAH}$ & 0.00 & 0.00 & 0.00 & 0.00 & 0.00 & 0.00 & 0.00 & 0.00 & 0.00 & 0.00 & 0.00 & 0.00 & 0.00 & 0.00 \\
\hline CAS & -0.41 & -0.41 & -0.41 & -0.41 & -0.41 & -0.41 & 0.00 & 0.00 & 0.00 & 0.00 & 0.00 & 0.00 & 0.00 & 4.32 \\
\hline MAI & -2.09 & -2.13 & -2.13 & -2.15 & -2.15 & -2.15 & 0.00 & 0.00 & -0.43 & -0.43 & -0.59 & -0.59 & -0.59 & 23.23 \\
\hline RIC & -0.39 & -0.39 & -0.39 & -0.39 & -0.39 & -0.39 & 0.00 & 0.00 & 0.00 & 0.00 & 0.00 & 0.00 & 0.00 & 4.01 \\
\hline SOR & -0.25 & -0.25 & -0.25 & -0.25 & -0.25 & -0.25 & 0.0 & 0.0 & 0.00 & 0.00 & 0.00 & 0.00 & 0.00 & 2.67 \\
\hline BEA & -0.47 & -0.47 & -0.47 & -0.47 & -0.47 & -0.47 & 0.0 & 0.0 & 0.00 & 0.00 & 0.00 & 0.00 & 0.00 & 4.87 \\
\hline OCC & -1.94 & $-1, .94$ & -1.94 & -1.94 & -1.94 & -1.94 & 0.00 & 0.00 & 0.00 & 0.00 & 0.00 & 0.00 & 0.00 & 21.10 \\
\hline
\end{tabular}

Table 6

Soil depth by agricultural industries in the different scenarios

\begin{tabular}{|c|c|c|c|c|c|c|c|c|c|c|c|c|c|c|}
\hline \multirow[t]{2}{*}{$D$} & \multicolumn{7}{|c|}{ Average growth 1991-2000 (\%) } & \multicolumn{7}{|c|}{ Level difference from baseline (A) in $2000(\%)$} \\
\hline & A & B & $\mathrm{C}$ & $\mathrm{D}$ & $\mathrm{E}$ & $\mathrm{F}$ & M & $\mathrm{A}^{\mathrm{a}}$ & B & $\mathrm{C}$ & $\mathrm{D}$ & E & $\mathrm{F}$ & M \\
\hline COT & -0.34 & -0.34 & -0.34 & -0.34 & -0.34 & -0.34 & -0.34 & 0.193 & 0 & 0 & 0 & 0 & 0 & 0 \\
\hline $\mathrm{COF}$ & -0.17 & -0.17 & -0.17 & -0.17 & -0.17 & -0.17 & -0.17 & 0.197 & 0 & 0 & 0 & 0 & 0 & 0 \\
\hline TEA & -0.17 & -0.17 & -0.17 & -0.17 & -0.17 & -0.17 & -0.17 & 0.197 & 0 & 0 & 0 & 0 & 0 & 0 \\
\hline TOB & -0.28 & -0.28 & -0.23 & -0.23 & -0.23 & -0.23 & -0.28 & 0.194 & 0.00 & 0.52 & 0.52 & 0.52 & 0.52 & 0.00 \\
\hline $\mathrm{CAH}$ & -0.22 & -0.22 & -0.22 & -0.22 & -0.22 & -0.22 & -0.22 & 0.196 & 0 & 0 & 0 & 0 & 0 & 0 \\
\hline CAS & -0.34 & -0.34 & -0.34 & -0.34 & -0.34 & -0.34 & -0.34 & 0.193 & 0 & 0 & 0 & 0 & 0 & 0 \\
\hline MAI & -0.51 & -0.51 & -0.51 & -0.51 & -0.51 & -0.51 & -0.51 & 0.190 & 0 & 0 & 0 & 0 & 0 & 0 \\
\hline RIC & -0.06 & -0.06 & -0.06 & -0.06 & -0.06 & -0.06 & -0.06 & 0.199 & 0 & 0 & 0 & 0 & 0 & 0 \\
\hline SOR & -0.51 & -0.51 & -0.51 & -0.51 & -0.51 & -0.51 & -0.51 & 0.190 & 0 & 0 & 0 & 0 & 0 & 0 \\
\hline BEA & -0.46 & -0.46 & -0.46 & -0.46 & -0.46 & -0.46 & -0.46 & 0.191 & 0 & 0 & 0 & 0 & 0 & 0 \\
\hline OCC & -0.34 & -0.34 & -0.34 & -0.34 & -0.34 & -0.34 & -0.34 & 0.193 & 0 & 0 & 0 & 0 & 0 & 0 \\
\hline
\end{tabular}

${ }^{\text {a }}$ Soil depth measured in metres in the year 2000 in baseline scenario A.

Table 7

Use of homogeneous land by agricultural industries in the different scenarios

\begin{tabular}{|c|c|c|c|c|c|c|c|c|c|c|c|c|c|c|}
\hline \multirow[t]{2}{*}{ KL } & \multicolumn{7}{|c|}{ Average growth $1991-2000(\%)$} & \multicolumn{7}{|c|}{ Level difference from baseline (A) in $2000(\%)$} \\
\hline & A & B & $\mathrm{C}$ & $\mathrm{D}$ & E & $\mathrm{F}$ & M & A & B & $\mathrm{C}$ & $\mathrm{D}$ & E & $\mathrm{F}$ & M \\
\hline COT & 1.17 & 1.54 & 2.88 & 7.91 & 7.60 & 6.39 & 2.06 & 0 & 3 & 17 & 83 & 78 & 60 & 8 \\
\hline TEA & 3.39 & 3.39 & 4.51 & 9.19 & 9.19 & 7.70 & 2.16 & 0 & 0 & 11 & 68 & 68 & 47 & -11 \\
\hline CAH & 0.00 & 3.20 & 4.51 & 8.59 & 8.59 & 7.70 & 1.71 & 0 & 33 & 50 & 117 & 117 & 100 & 17 \\
\hline CAS & -0.08 & -0.16 & -0.08 & 0.40 & 0.32 & 0.16 & -0.33 & 0 & -1 & 0 & 4 & 4 & 2 & -3 \\
\hline MAI & 1.72 & 2.15 & 2.28 & 3.41 & 3.27 & 2.91 & 0.00 & 0 & 4 & 5 & 16 & 15 & 11 & -16 \\
\hline RIC & 0.55 & 0.37 & 0.55 & 2.06 & 1.90 & 1.25 & 0.46 & 0 & -2 & 0 & 15 & 13 & 6 & -1 \\
\hline SOR & 0.00 & 0.00 & 0.00 & 1.21 & 1.02 & 0.62 & 0.00 & 0 & 0 & 0 & 12 & 10 & 6 & 0 \\
\hline BEA & 0.09 & 0.17 & 0.26 & 1.07 & 0.91 & 0.59 & -0.17 & 0 & 1 & 2 & 9 & 8 & 5 & -3 \\
\hline OCC & 1.89 & 1.71 & 1.95 & 4.52 & 4.33 & 3.52 & 0.98 & 0 & -2 & 1 & 27 & 25 & 16 & -9 \\
\hline
\end{tabular}




\section{Appendix B. Equations of the model}

\begin{tabular}{|c|c|c|c|}
\hline & Economic model & List & Numbers \\
\hline 1 & $X_{i}=\operatorname{tech}_{i} \times$ bbhat $_{i} \times L_{i}^{\alpha_{i}} \times \mathrm{kk}_{i}^{\beta_{i}} \times F_{i}^{\gamma_{i}} \times \mathrm{PA}_{i}^{\chi_{i}} \times \mathrm{KL}_{i}^{\mu_{i}}$ & $i=\mathrm{AG} 1$ & 9 \\
\hline 2 & $X_{i}=\operatorname{tech}_{i} \times$ bbhat $_{i} \times L_{i}^{\alpha_{i}} \times \mathrm{kk}_{i}^{\beta_{i}} \times F_{i}^{\gamma_{i}} \times \mathrm{PA}_{i}^{\chi_{i}} \times \mathrm{kl}_{i}^{\mu_{i}}$ & $i=\mathrm{AG} 2$ & 2 \\
\hline 3 & $X_{i}=\operatorname{tech}_{i} \times \mathrm{bb}_{i} \times L_{i}^{\alpha_{i}} \times \mathrm{kk}_{i}^{\beta_{i}}$ & $i=\mathrm{IND}$ & 9 \\
\hline 4 & $w L_{i}=\alpha_{i} X_{i}\left(P_{i}-\sum_{j} \mathrm{PC}_{j}\left(1+\mathrm{ta}_{j}\right) a_{j i}\right)$ & $i=Z, j=J$ & 20 \\
\hline 5 & $\mathrm{PC}_{\mathrm{pes}}\left(1+\mathrm{ta}_{\mathrm{pes}}\right) \mathrm{PA}_{i}=\chi_{i} X_{i}\left(P_{i}-\sum_{j} \mathrm{PC}_{j}\left(1+\mathrm{ta}_{j}\right) a_{j i}\right)$ & $i=\mathrm{AG}, j=J$ & 11 \\
\hline 6 & $\mathrm{PC}_{\text {fer }}\left(1+\mathrm{ta}_{\mathrm{fer}}\right) F_{i}=\gamma_{i} X_{i}\left(P_{i}-\sum_{j} \mathrm{PC}_{j}\left(1+\mathrm{ta}_{j}\right) a_{j i}\right)$ & $i=\mathrm{AG}, j=J$ & 11 \\
\hline 7 & $\mathrm{pkl}_{i} \times \mathrm{KL}_{i}=\operatorname{lan}_{i} \times \mathrm{PRFT}_{i}$ & $i=\mathrm{AG} 1$ & 9 \\
\hline 8 & $\mathrm{PKL}_{i} \times \mathrm{kl}_{i}=\operatorname{lan}_{i} \times \mathrm{PRFT}_{i}$ & $i=\mathrm{AG} 2$ & 2 \\
\hline 9 & $\mathrm{PC}_{i} \times \mathrm{XC}_{i}=\left(1+\mathrm{td}_{i}\right) \times \mathrm{PD}_{i} \times \mathrm{XD}_{i}$ & $i=\mathrm{NIM}$ & 11 \\
\hline 10 & $\mathrm{PC}_{i} \times \mathrm{XC}_{i}=\left(1+\mathrm{td}_{i}\right) \times \mathrm{PD}_{i} \times \mathrm{XD}_{i}+\mathrm{pm}_{i} \times\left(1+\mathrm{tm}_{i}\right) \times M_{i}$ & $i=\mathrm{IM}$ & 11 \\
\hline 11 & $\mathrm{XC}_{i}=\mathrm{XD}_{i}$ & $i=\mathrm{NIM}$ & 11 \\
\hline 12 & $\mathrm{XC}_{i}=\mathrm{qq}_{i}\left[q_{i} M_{i}^{-\tau}+\left(1-q_{i}\right) \mathrm{XD}_{i}^{-\tau}\right]^{-1 / \tau}$ & $i=\mathrm{IM} 1$ & 9 \\
\hline 13 & $\mathrm{XC}_{i}=M_{i}$ & $i=\mathrm{CHEM}$ & 2 \\
\hline 14 & $M_{i} / \mathrm{XD}_{i}=\left[\left(\left(\mathrm{PD}_{i}\left(1+\operatorname{td}_{i}\right)\right) /\left(\operatorname{pm}_{i}\left(1+\operatorname{tm}_{i}\right)\right)\right)\left(q_{i} /\left(1-q_{i}\right)\right)\right]^{1 /(1+\tau)}$ & $i=\mathrm{IM} 1$ & 9 \\
\hline 15 & $P_{i} X_{i}=\mathrm{PD}_{i} \times \mathrm{XD}_{i}$ & $i=\mathrm{NEX}$ & 7 \\
\hline 16 & $P_{i} X_{i}=\mathrm{PD}_{i} \times \mathrm{XD}_{i}+\mathrm{pe}_{i} \times E_{i}$ & $i=\mathrm{EX}$ & 13 \\
\hline 17 & $X_{i}=\mathrm{XD}_{i}$ & $i=\mathrm{NEX}$ & 7 \\
\hline 18 & $X_{i}=\operatorname{hh}_{i}\left[h_{i} E_{i}^{\rho}+\left(1-h_{i}\right) \mathrm{XD}_{i}^{\rho}\right]^{1 / \rho}$ & $i=\mathrm{EX}$ & 13 \\
\hline 19 & $E_{i} / \mathrm{XD}_{i}=\left[\left(\mathrm{pe}_{i} / \mathrm{PD}_{i}\right)\left(\left(1-h_{i}\right) / h_{i}\right)\right]^{1 /(\rho-1)}$ & $i=\mathrm{EX}$ & 13 \\
\hline 20 & $\begin{array}{l}\operatorname{PRFT}_{i}=X_{i}\left[P_{i}-\sum_{j} a_{j i} \times \mathrm{PC}_{j} \times\left(1+\mathrm{ta}_{j}\right)\right]- \\
w L_{i}-\mathrm{PC}_{\mathrm{pes}}\left(1+\mathrm{ta}_{\mathrm{pes}}\right) \mathrm{PA}_{i}-\mathrm{PC}_{\mathrm{fer}}\left(1+\mathrm{ta}_{\mathrm{fer}}\right) F_{i}\end{array}$ & $i=\mathrm{AG}, j=J$ & 11 \\
\hline 21 & $\operatorname{PRFT}_{i}=X_{i}\left[P_{i}-\sum_{j} a_{j i} \times \mathrm{PC}_{j} \times\left(1+\mathrm{ta}_{j}\right)\right]-w L_{i}$ & $i=\mathrm{IND}, j=J$ & 9 \\
\hline 22 & $Y=\sum_{i}\left(w L_{i}+\mathrm{PRFT}_{i}\right)+w \times \lg$ & $i=Z$ & 1 \\
\hline 23 & EXPEND $=c(1-$ ty $) Y$ & & 1 \\
\hline 24 & $\mathrm{PC}_{i} \times \mathrm{CD}_{i}=\mathrm{PC}_{i} \times \theta_{i}+\kappa_{i}\left[\mathrm{EXPEND}-\sum_{j} \mathrm{PC}_{j} \times \theta_{j}\right]$ & $i=J, j=J$ & 22 \\
\hline 25 & $\begin{array}{l}\mathrm{GR}=\operatorname{ty} \times Y+\sum_{j} \mathrm{td}_{j} \times \mathrm{PD}_{j} \times \mathrm{XD}_{j}+\sum_{l} \mathrm{te}_{l} \times \mathrm{pe}_{l} \times \\
E_{l}+\sum_{i} \mathrm{tm}_{i} \times \mathrm{pm}_{i} \times M_{i}+\sum_{k} \mathrm{ta}_{\mathrm{pes}} \times \mathrm{PC}_{\mathrm{pes}} \times \mathrm{PA}_{k}+ \\
\sum_{k} \mathrm{ta}_{\mathrm{fer}} \times \mathrm{PC}_{\mathrm{fer}} \times F_{k}+\sum_{n} \sum_{j} \mathrm{ta}_{n} \times \mathrm{PC}_{n} \times a_{n j} \times X_{j}\end{array}$ & $\begin{array}{l}j=Z, l=\mathrm{EX}, i=\mathrm{IM} \\
k=\mathrm{AG}, n=J\end{array}$ & 1 \\
\hline 26 & $\mathrm{SGOV}=\mathrm{GR}-\sum_{i} \mathrm{PC}_{i} \times \mathrm{gc}_{i}-w \times \mathrm{lg}$ & $i=J$ & 1 \\
\hline 27 & $\mathrm{JJ}=(1-c)(1-$ ty $) Y+\mathrm{SGOV}-\sum_{i} \mathrm{PC}_{i} \times \mathrm{cs}_{i}-\mathrm{er} \times$ sfor & $i=J$ & 1 \\
\hline 28 & $\mathrm{PC}_{j} \times \mathrm{DK}_{j i}=$ imat $_{j i} \times$ kshare $_{i} \times \mathrm{JJ}$ & $i=\mathrm{I} 1, j=\mathrm{I} 2$ & 28 \\
\hline 29 & $\mathrm{XC}_{i}=\sum a_{i j} X_{j}+\mathrm{cs}_{i}+\mathrm{gc}_{i}+\mathrm{CD}_{i}$ & $i=\mathrm{I} 3, j=Z$ & 18 \\
\hline 30 & $\mathrm{XC}_{i}=\sum a_{i j} X_{j}+\mathrm{cs}_{i}+\mathrm{gc}_{i}+\mathrm{CD}_{i}+\sum_{l} \mathrm{DK}_{i l}$ & $i=\mathrm{I} 2, l=\mathrm{I} 1$ & 2 \\
\hline 31 & $\mathrm{XC}_{i}=\sum_{k} \mathrm{PA}_{k}+\sum_{j} a_{i j} X_{j}+\mathrm{cs}_{i}+\mathrm{gc}_{i}+\mathrm{CD}_{i}$ & $i=$ pes, $j=Z, k=\mathrm{AG}$ & 1 \\
\hline \multirow[t]{2}{*}{32} & $\mathrm{XC}_{i}=\sum_{k} F_{k}+\sum_{j} a_{i j} X_{j}+\mathrm{cs}_{i}+\mathrm{gc}_{i}+\mathrm{CD}_{i}$ & $i=\mathrm{fer}, j=Z, k=\mathrm{AG}$ & 1 \\
\hline & & sum: & 276 \\
\hline
\end{tabular}




\begin{tabular}{|c|c|c|c|}
\hline & Soil model & List & Numbers \\
\hline 33 & $\begin{aligned} \text { bbhat }_{i} & =\mathrm{bb}_{i}\left(\left(\left(a_{0 i}+a_{1 i} \times \mathrm{NR}_{i}\right)\left(\text { phis }_{i}\right)^{\left(b_{0 i}+b_{1 i} \times \mathrm{NR}_{i}\right)}\right) / \text { bbnorm }_{i}\right) \\
\text { bbhat }_{i} & =\mathrm{bb}_{i}\end{aligned}$ & $\begin{array}{l}i=\mathrm{AG} 5 \\
i=\mathrm{cah}\end{array}$ & $\begin{array}{r}10 \\
1\end{array}$ \\
\hline 34 & $\mathrm{NR}_{i}=\left[\mathrm{rns} \times \mathrm{NS}_{i}+(1 / 3) \sum_{s=2}^{4} \mathrm{NRR}_{i, t-s}+\mathrm{nas}\right] / 2$ & $i=\mathrm{AG}$ & 11 \\
\hline 35 & $\mathrm{NS}_{i}=(1-\mathrm{rns}) \mathrm{NS}_{i, t-1}+\left(1-l_{i}\right) \mathrm{NRR}_{i, t-1}-\mathrm{NE}_{i, t-1}$ & $i=\mathrm{AG}$ & 11 \\
\hline 36 & $\begin{array}{l}\mathrm{NRR}_{i}=\operatorname{exxs}_{i}\left(X_{i} / \mathrm{KL}_{i}\right)\left(\operatorname{retain}_{i} \times \mathrm{ncss}_{i} \times\right. \\
\left.\left(\left(1-\mathrm{hs}_{i}\right) / \mathrm{hs}_{i}\right)+\operatorname{ncrs}_{i}\left(1 /\left(\mathrm{hs}_{i} \times \operatorname{srs}_{i}\right)\right)\right)\end{array}$ & $i=\mathrm{AG}$ & 11 \\
\hline 37 & $\mathrm{NE}_{i}=\mathrm{rs}_{i} \times \mathrm{ks} \times \mathrm{ss}_{i} \times \mathrm{ws} \times \mathrm{ms} \times\left(\mathrm{NS}_{i} /\left(\mathrm{bds} \times 10 \times D_{i}\right)\right) \times \mathrm{cpa}_{i}$ & $i=\mathrm{AG} 3$ & 2 \\
\hline 38 & $\begin{array}{l}\mathrm{NE}_{i}=\mathrm{rs}_{i} \times \mathrm{ks} \times \mathrm{ss}_{i} \times \mathrm{ws} \times \mathrm{ms} \times\left(\mathrm{NS}_{i} /(\mathrm{bds} \times\right. \\
\left.\left.10 \times D_{i}\right)\right) \times\left(\mathrm{cp}_{i}-\text { cpars }_{i} \times \operatorname{exxs}_{i} \times\left(X_{i} / \mathrm{KL}_{i}\right)\right)\end{array}$ & $i=\mathrm{AG} 4$ & 8 \\
\hline 39 & $\begin{array}{l}\mathrm{NE}_{i}=\mathrm{rs}_{i} \times \mathrm{ks} \times \mathrm{ss}_{i} \times \mathrm{ws} \times \mathrm{ms} \times\left(\mathrm{NS}_{i} /(\mathrm{bds} \times\right. \\
\left.10 \times D_{i}\right) \times\left(\mathrm{cp}_{i}-\text { cpars }_{i} \times \operatorname{exxs}_{i} \times\left(X_{i} / \mathrm{kl}_{i}\right)\right)\end{array}$ & $i=$ tob & 1 \\
\hline 40 & $D_{i}=D_{i, t-1}-\left(\mathrm{rs}_{i} \times \mathrm{ks} \times \mathrm{ss}_{i} \times \mathrm{ws} \times \mathrm{cpa}_{i} /(\mathrm{bds} \times 10)\right)$ & $i=\mathrm{AG} 3$ & 2 \\
\hline 41 & $\begin{array}{l}D_{i}=D_{i, t-1}-\left(\mathrm{rs}_{i} \times \mathrm{ks} \times \mathrm{ss}_{i} \times \mathrm{ws} \times\left(\mathrm{cp}_{i}\right.\right. \\
\left.\left.-\operatorname{cpars}_{i} \times \operatorname{exxs}_{i} \times\left(X_{i} / \mathrm{KL}_{i}\right)\right) /(\mathrm{bds} \times 10)\right)\end{array}$ & $i=\mathrm{AG} 4$ & 8 \\
\hline \multirow[t]{2}{*}{42} & $\begin{array}{l}D_{i}=D_{i, t-1}-\left(\mathrm{rs}_{i} \times \mathrm{ks} \times \mathrm{ss}_{i} \times \mathrm{ws} \times\left(\mathrm{cp}_{i}\right.\right. \\
\left.\left.-\operatorname{cpars}_{i} \times \operatorname{exxs}_{i} \times\left(X_{i} / \mathrm{kl}_{i}\right)\right) /(\operatorname{bds} \times 10)\right)\end{array}$ & $i=$ tob & 1 \\
\hline & & sum: & 66 \\
\hline
\end{tabular}

\section{Appendix C. List of variables and parameters}

\section{C.1. Endogenous variables}

Economic model:

\begin{tabular}{llrl}
\hline CD & Private consumption of goods & 22 & $J$ \\
DK & Real investment of goods in industries & 28 & I1/I2 \\
$E$ & Exports from industries & 13 & EX \\
EXPEND & Total nominal private expenditure on consumption & 1 & \\
$F$ & Use of fertilisers in agricultural industries & 11 & AG \\
GR & Government nominal net revenues & 1 & \\
JJ & Total nominal real investment expenditure & 1 & \\
KL & Units of homogeneous land & 9 & AG1 \\
$L$ & Use of labour & 20 & $Z$ \\
$M$ & Import of goods & 11 & $\mathrm{IM}$ \\
$P$ & Producer price of composite deliveries & 20 & $Z$ \\
PA & Use of pesticides in agricultural industries & 11 & AG \\
PC & Composite purchaser price & 22 & $J$ \\
PD & Producers price on home market deliveries & 20 & $Z$
\end{tabular}


Appendix C (Continued)

\begin{tabular}{llrr}
\hline PKL & Price of homogenous land in 'cof' and 'tob' & 2 & AG2 \\
PRFT & Total nominal profits in the industries & 20 & $Z$ \\
SGOV & Government nominal savings & 1 & $Z$ \\
$X$ & Units of production by industries & 20 & $\mathrm{~J}$ \\
XC & Units of composite purchaser goods & 22 & $Z$ \\
XD & Units delivered to the home market & 20 & 1 \\
$Y$ & Nominal private income & 276 \\
\hline
\end{tabular}

Soil model:

\begin{tabular}{llll}
\hline bbhat & Soil productivity parameter (here variable) & 11 & AG \\
$D$ & Soil depth & 11 & AG \\
NE & Lost nitrogen due to erosion & 11 & AG \\
NR & Naturally mineralised nitrogen & 11 & AG \\
NRR & Nitrogen from roots and residues & 11 & AG \\
NS & Stock of nitrogen in Soil Organic Matter & 11 & AG \\
& & 66 & \\
\hline
\end{tabular}

\section{C.2. Parameters and exogenous variables}

Economic model:

\begin{tabular}{ll}
\hline$\alpha$ & Productivity of labour in production function \\
$\beta$ & Productivity of real capital in production function \\
$\gamma$ & Productivity of fertilisers in production functions for agricultural industries \\
$\chi$ & Productivity of pesticides in production functions for agricultural industries \\
$\mu$ & Productivity of homogeneous land in production functions for agricultural industries \\
$\theta$ & Basic consumption in LES functions \\
$\kappa$ & Budget share of available expenditure after spending on basic consumption \\
$\tau$ & Substitution elasticity for consumption between imports and home produced goods \\
$\rho$ & Transformation elasticity between exports and home market deliveries in production \\
$a$ & Units input of goods per unit output of goods in industries \\
$\mathrm{bb}$ & Calibration coefficient in non-agricultural industries \\
$\mathrm{bbhat}$ & Soil productivity parameter \\
$c$ & Marginal propensity to consume \\
$\mathrm{cs}$ & Change in stocks \\
$\mathrm{er}$ & Currency exchange rate (T.sh./USD) \\
$\mathrm{gc}$ & Government real consumption \\
$h$ & Export share parameter in the export/home market transformation function \\
$\mathrm{hh}$ & Shift parameter in the export/home market transformation function \\
$\mathrm{imat}$ & Each investment good's share of nominal expenditure on investment in industries \\
$\mathrm{kshare}$ & Each industry share of total nominal expenditure on investment \\
&
\end{tabular}




\begin{tabular}{ll} 
Appendix C (Continued) & \\
\hline $\operatorname{lan}$ & Land resource rent share of total profits in agricultural industries \\
$\mathrm{lg}$ & Governmental use of labour \\
$\mathrm{pkl}$ & Price of homogeneous land in agricultural industries where use of land is endogenous \\
$\mathrm{pe}$ & Unit price to the producer for export goods \\
$\mathrm{pm}$ & Unit price of imports at the border \\
$q$ & Import share parameter in the import/home market substitution function \\
$\mathrm{qq}$ & Shift parameter in the import/home market substitution function \\
$\mathrm{sfor}$ & Nominal financial transfers abroad (USD) \\
$\mathrm{ta}$ & Subsidy rate \\
$\mathrm{td}$ & Taxation rate on goods delivered to the home market \\
$\mathrm{te}$ & Taxation rate on goods for export \\
$\mathrm{tech}$ & Technological productivity parameter \\
$\mathrm{tm}$ & Taxation rate on imported goods \\
$\mathrm{ty}$ & Income taxation rate \\
$w$ & Nominal wage \\
\hline
\end{tabular}

Soil model:

\begin{tabular}{ll}
\hline$\lambda$ & Percentage direct mineralisation from roots and stover \\
$a_{0}$ & Parameter in soil productivity index \\
$a_{1}$ & Parameter in soil productivity index \\
$b_{0}$ & Parameter in soil productivity index \\
$b_{1}$ & Parameter in soil productivity index \\
bb & Calibration constants in the production function in the base year \\
bbnorms & Normalised calibration constant \\
bds & Soil density \\
cp & Vegetation cover function coefficient \\
cpa & Vegetation cover index \\
cpars & Vegetation cover function coefficient \\
crs & Nitrogen concentration in roots \\
exxs & Transfer parameter for crops from money to physical units \\
hs & Food's share of food and stover \\
ks & Erodability of the soil index \\
nas & Atmospheric nitrogen deposition \\
ncss & Nitrogen concentration in stover \\
phis & Transfer parameter for nitrogen from money to physical units \\
ms & Nitrogen content in eroded soil \\
retain & Proportion of stover kept in soil \\
rns & Nitrogen mineralisation from SON \\
rs & Climate and rainfall index \\
srs & Proportion food and stover to roots \\
ss & Slope index \\
ws & Depletion of eroded soil index \\
\end{tabular}




\section{Appendix D}

List of industries and goods ${ }^{\mathrm{a}}$

$J \quad Z$ AG AG1 AG2 AG3 AG4 AG5 IND I1 I2 I3 IM IM1 NIM EX NEX CHEM

\begin{tabular}{|c|c|c|c|c|c|c|c|c|c|c|c|c|c|c|c|c|}
\hline cot: cotton & $\mathrm{X}$ & $X X$ & $\mathrm{X}$ & & & $\mathrm{X}$ & $\mathrm{X}$ & & & $\mathrm{X}$ & & & $\mathrm{X}$ & $\mathrm{X}$ & & \\
\hline cof: coffee & $\mathrm{X}$ & $\mathrm{X} X$ & & $\mathrm{X}$ & & $\mathrm{X}$ & $\mathrm{X}$ & & $\mathrm{X}$ & $\mathrm{X}$ & & & $\mathrm{X}$ & $\mathrm{X}$ & & \\
\hline tea: tea & $X$ & $X X$ & $\mathrm{X}$ & & $\mathrm{X}$ & & $\mathrm{X}$ & & $X$ & $\mathrm{X}$ & & & $\mathrm{X}$ & $\mathrm{X}$ & & \\
\hline tob: tobacco & $X$ & $X X$ & & $\mathrm{X}$ & & & $\mathrm{X}$ & & $X$ & $X X$ & $X$ & $\mathrm{X}$ & & $\mathrm{X}$ & & \\
\hline cah: cashew & $X$ & $X X$ & $\mathrm{X}$ & & $\mathrm{X}$ & & & & $\mathrm{X}$ & $\mathrm{X}$ & & & $\mathrm{X}$ & $\mathrm{X}$ & & \\
\hline cas: cassava & $\mathrm{X}$ & $X X$ & $\mathrm{X}$ & & & $\mathrm{X}$ & $\mathrm{X}$ & & & $\mathrm{X}$ & & & $\mathrm{X}$ & & $\mathrm{X}$ & \\
\hline mai: maize & $\mathrm{X}$ & $X X$ & $\mathrm{X}$ & & & $X$ & $\mathrm{X}$ & & $\mathrm{X}$ & $\mathrm{X}$ & & & $\mathrm{X}$ & & $\mathrm{X}$ & \\
\hline ric: rice & $\mathrm{X}$ & $X \quad X$ & $\mathrm{X}$ & & & $\mathrm{X}$ & $\mathrm{X}$ & & & $\mathrm{X} x$ & $X$ & $\mathrm{X}$ & & & $\mathrm{X}$ & \\
\hline sor: sorghum & $\mathrm{X}$ & $X X$ & $\mathrm{X}$ & & & $\mathrm{X}$ & $\mathrm{X}$ & & & $\mathrm{X}$ & & & $\mathrm{X}$ & & $\mathrm{X}$ & \\
\hline bea: beans & $\mathrm{X}$ & $X X$ & $\mathrm{X}$ & & & $\mathrm{X}$ & $\mathrm{X}$ & & & $\mathrm{X}$ & & & $\mathrm{X}$ & & $\mathrm{X}$ & \\
\hline occ: other crops & $\mathrm{X}$ & $X X$ & $\mathrm{X}$ & & & $\mathrm{X}$ & $\mathrm{X}$ & & & $X Y$ & $X$ & $\mathrm{X}$ & & $X$ & & \\
\hline liv: livestock & $\mathrm{X}$ & $\mathrm{X}$ & & & & & & $\mathrm{X}$ & $\mathrm{X}$ & X & $X$ & $\mathrm{X}$ & & $\mathrm{X}$ & & \\
\hline for: forestry & $\mathrm{X}$ & $\mathrm{X}$ & & & & & & $\mathrm{X}$ & $\mathrm{X}$ & $X r$ & $X$ & $\mathrm{X}$ & & $\mathrm{X}$ & & \\
\hline foo: food & $\mathrm{X}$ & $\mathrm{X}$ & & & & & & $\mathrm{X}$ & $\mathrm{X}$ & X $>$ & $\mathrm{X}$ & $\mathrm{X}$ & & $\mathrm{X}$ & & \\
\hline tex: textiles & $\mathrm{X}$ & $\mathrm{X}$ & & & & & & $\mathrm{X}$ & $\mathrm{X}$ & $X>$ & $X$ & $\mathrm{X}$ & & $\mathrm{X}$ & & \\
\hline oms: other manufacture & $\mathrm{X}$ & $\mathrm{X}$ & & & & & & $\mathrm{X}$ & $\mathrm{X} X$ & & $X$ & $\mathrm{X}$ & & $\mathrm{X}$ & & \\
\hline con: construction & $\mathrm{X}$ & $\mathrm{X}$ & & & & & & $\mathrm{X}$ & $\mathrm{X} X$ & & & & $\mathrm{X}$ & & $\mathrm{X}$ & \\
\hline ele: electricity & $\mathrm{X}$ & $\mathrm{X}$ & & & & & & $\mathrm{X}$ & $X$ & $X$ & & & $\mathrm{X}$ & & $\mathrm{X}$ & \\
\hline tra: transport & $X$ & $\mathrm{X}$ & & & & & & $\mathrm{X}$ & $\mathrm{X}$ & $\mathrm{X}$ & & & $\mathrm{X}$ & $\mathrm{X}$ & & \\
\hline ops: other private services & $\mathrm{X}$ & $\mathrm{X}$ & & & & & & $\mathrm{X}$ & $\mathrm{X}$ & X 2 & $X$ & $\mathrm{X}$ & & $\mathrm{X}$ & & \\
\hline fer: fertilisers & $\mathrm{X}$ & & & & & & & & & & $\mathrm{X}$ & & & & & $\mathrm{X}$ \\
\hline pes: pesticides & $\mathrm{X}$ & & & & & & & & & & $X$ & & & & & $\mathrm{X}$ \\
\hline Sum & 22 & 2011 & 9 & 2 & 2 & 8 & 10 & 9 & 142 & 18 & 11 & 9 & 11 & 13 & 7 & 2 \\
\hline
\end{tabular}

a $J$ : goods; $Z$ : industries; AG: agricultural industries; AG1: agricultural with variable use of land; AG2: agriculture with constant use of land; AG3: agriculture with constant soil erosion; AG4: agriculture with variable soil erosion; AG5: agriculture with variable soil productivity; IND: production industries; I1: capital utilising industries; I2: capital producing industries; I3: non-capital producing industries; IM: imported goods; IM1: imported goods, less agro-chemicals; NIM: non-imported goods; EX: exporting industries; NEX: non-exporting industries; CHEM: agro-chemical goods. 


\section{Appendix E. The Social Accounting Matrix for Tanzania (1990 million T.sh.)}

\begin{tabular}{|c|c|c|c|c|c|c|c|c|c|c|c|c|c|c|c|c|c|c|}
\hline \multirow[t]{2}{*}{ Goods } & \multirow[t]{2}{*}{ GP } & \multirow{2}{*}{ Imports } & \multirow{2}{*}{$\begin{array}{l}\text { Tax on } \\
\text { imports }\end{array}$} & \multicolumn{10}{|c|}{$\underline{\text { Sectors }}$} & \multirow{2}{*}{$\begin{array}{l}\text { Private } \\
\text { investment }\end{array}$} & \multirow{2}{*}{$\begin{array}{l}\text { Government } \\
\text { consumption }\end{array}$} & \multirow{2}{*}{$\begin{array}{l}\text { Private } \\
\text { consumption }\end{array}$} & \multirow[t]{2}{*}{ Exports } & \multirow{2}{*}{$\begin{array}{l}\text { Change in } \\
\text { stocks }\end{array}$} \\
\hline & & & & $\cot$ & cof & tea & tob & cah & cas & mai & ric & sor & bea & & & & & \\
\hline $\cot$ & 8208 & & & 687 & & & & & & & & & & & & & & \\
\hline cof & 10932 & & & & 90 & & & & & & & & & & & & & \\
\hline tea & 1530 & & & & & 185 & & & & & & & & & & & & \\
\hline tob & 1576 & 41 & & & & & 140 & & & & & & & & & & & \\
\hline cah & 1674 & & & & & & & & & & & & & & & & & \\
\hline cas & 9396 & & & & & & & & & & & & & & & & & \\
\hline mai & 26895 & & & & & & & & & 2600 & & & & & & & & \\
\hline ric & 9139 & 551 & & & & & & & & & 612 & & & & & & & \\
\hline sor & 4118 & & & & & & & & & & & 334 & & & & & & \\
\hline bea & 10579 & & & & & & & & & & & & 1425 & & & & & \\
\hline occ & 67404 & 5162 & 566 & & & & & & & & & & & & & & & \\
\hline liv & 42560 & 1121 & & & & & & & & & & & & & & & & \\
\hline for & 17471 & 372 & & & & & & & & & & & & & & & & \\
\hline foo & 94634 & 3385 & 371 & & & & & & & & & & & & & & & \\
\hline tex & 69057 & 6435 & 706 & 420 & 32 & & 90 & 390 & 120 & 1170 & 450 & 180 & 90 & & & & & \\
\hline oms & 245147 & 209142 & 24106 & & & & & & & & & & & & & & & \\
\hline con & 61757 & & & & & & & & & & & & & & & & & \\
\hline ele & 7890 & & & & & & & & & & & & & & & & & \\
\hline tra & 50725 & & & 632 & 175 & 7 & 90 & 20 & & 2271 & 166 & 54 & 158 & & & & & \\
\hline ops & 192367 & 16487 & 1809 & & & & & & & & & & & & & & & \\
\hline fer & & 3844 & & 86 & 266 & 84 & 367 & & & 2801 & & & 240 & & & & & \\
\hline pes & & 5943 & & 1173 & 3582 & & & 1188 & & & & & & & & & & \\
\hline Sum & 933059 & 252483 & 27558 & 2998 & 4145 & 276 & 687 & 1598 & 120 & 8842 & 1228 & 568 & 1913 & & & & & \\
\hline Operating surplus & & & & & 133 & 165 & 14 & 17 & & 953 & & & & & & & & \\
\hline Compensation of employees & & & & 4755 & 3546 & 841 & 514 & 359 & 9276 & 18781 & 7911 & 3550 & 8810 & & & & & \\
\hline Indirect taxes on production & & & & 455 & 3108 & 248 & 361 & -300 & & -1681 & & & -144 & & & & & \\
\hline Export tax & & & & 1094 & 5059 & 298 & 581 & 294 & & & & & & & & & & \\
\hline Sales tax & & & & & & & & & & & & & & & & & & \\
\hline Fertiliser subsidies & & & & -52 & -160 & -50 & -220 & & & -1681 & & & -144 & & & & & \\
\hline Pesticide subsidies & & & & -587 & -1791 & & & -594 & & & & & & & & & & \\
\hline Sum (GP) & & & & 8208 & 10932 & 1530 & 1576 & 1674 & 9396 & 26895 & 9139 & 4118 & 10579 & & & & & \\
\hline
\end{tabular}




\begin{tabular}{|c|c|c|c|c|c|c|c|c|c|c|c|c|c|c|c|}
\hline $\cot$ & & & & 5177 & & & & & & & & & & 2344 & \\
\hline $\begin{array}{l}\text { cof } \\
\text { tea }\end{array}$ & & & 706 & & & & & & & & & & & $\begin{array}{l}10842 \\
639\end{array}$ & \\
\hline tob & & & 232 & & & & & & & & & & & 1245 & \\
\hline cah & & & 564 & & & & & & & & & & 480 & 630 & \\
\hline cas & & & & & & & & & & & & & 9396 & & \\
\hline mai & & & 2516 & & & & & & & & & & 21779 & & \\
\hline ric & & & 2221 & & & & & & & & & & 6857 & & \\
\hline sor & & & 356 & & & & & & & & & & 3428 & & \\
\hline bea & & & & & & & & & 380 & & & & 8774 & & \\
\hline occ & & & 11091 & 7586 & 166 & & & & 7313 & 2059 & & & 36242 & 8675 & \\
\hline liv & & & 516 & & 1461 & & & & 4585 & & & 290 & 35974 & 855 & \\
\hline for & & 125 & 108 & & 1001 & 1174 & & & 7767 & & & 858 & 3394 & 3416 & \\
\hline foo & 1537 & & 5372 & & 826 & & & & 22695 & & & 214 & 83961 & 1168 & -17383 \\
\hline tex & 321 & 684 & 1464 & 4155 & 3033 & & & & 451 & 90 & & 295 & 39137 & 4439 & 19187 \\
\hline oms & 751 & 393 & 7890 & 17122 & 83511 & 21270 & 1998 & 5314 & 18916 & & 188618 & 5004 & 88058 & 9452 & 30098 \\
\hline con & & & 68 & 23 & 1776 & 86 & 124 & 1287 & 5214 & & 28785 & 424 & 23970 & & \\
\hline ele & & & 344 & 363 & 1774 & 40 & 60 & 111 & 1346 & & & 2752 & 1100 & & \\
\hline tra & & 96 & 1155 & 274 & 5689 & 1328 & 160 & 741 & 8383 & 1000 & & 1915 & 12411 & 14000 & \\
\hline ops & 1647 & 383 & 24185 & 16330 & 76403 & 10168 & 575 & 4628 & 28913 & & & 5751 & 19568 & 13522 & 8590 \\
\hline fer & & & & & & & & & & & & & & & \\
\hline pes & & & & & & & & & & & & & & & \\
\hline Sum & 4256 & 1681 & 58788 & 51030 & 175640 & 34066 & 2917 & 12081 & 105963 & 3149 & 217403 & 17503 & 394529 & 71227 & 40492 \\
\hline Operating surplus & 1915 & 789 & 15568 & 7522 & 22729 & 6391 & 4439 & 31115 & 29163 & & & & & & \\
\hline Compensation of employees & 36389 & 15001 & 6173 & 2981 & 9012 & 21302 & 534 & 7529 & 57241 & 64255 & & 35133 & & & \\
\hline Indirect taxes on production & & & 14105 & 7524 & 37766 & & & & & & & & & & \\
\hline Export tax & & & & & & & & & & & & & & & \\
\hline Sales tax & & & 14105 & 7524 & 37766 & & & & & & & & & & \\
\hline Fertiliser subsidies & & & & & & & & & & & & & & & \\
\hline Pesticide subsidies & & & & & & & & & & & & & & & \\
\hline Sum (GP) & 42560 & 17471 & 94634 & 69057 & 245147 & 61758 & 7890 & 50725 & 192367 & 67404 & & 52636 & & & \\
\hline
\end{tabular}




\section{Appendix F. Figure of the nitrogen cycle}

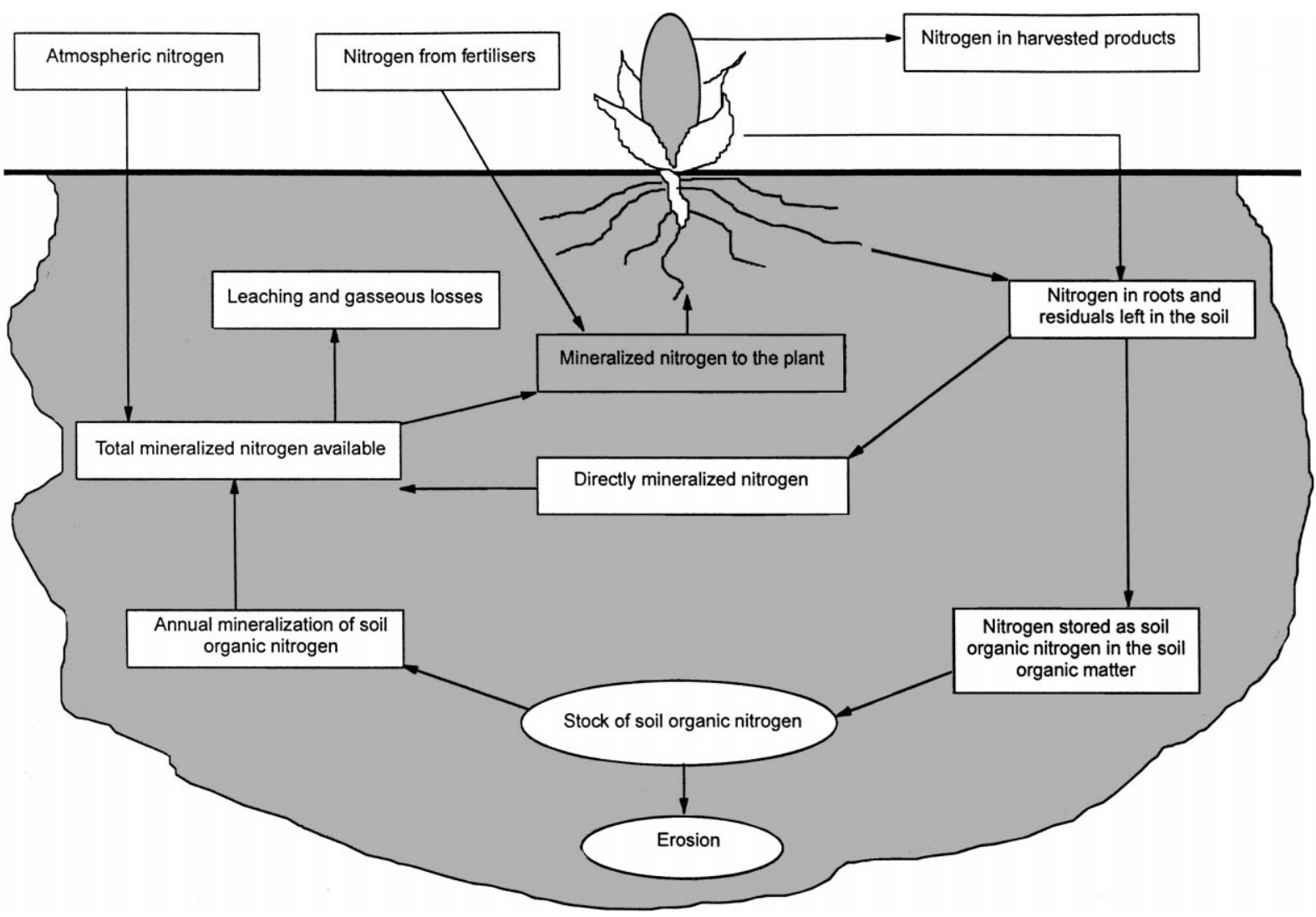

\section{Appendix G. Integrating the soil model in the CGE model}

The point of departure is a Cobb-Douglas production function of the following form:

$$
\frac{X}{\mathrm{KL}}=\mathrm{bb}^{\prime} \times I_{\mathrm{n}} \times\left(\frac{L}{\mathrm{KL}}\right)^{\alpha} \times\left(\frac{\mathrm{kk}}{\mathrm{KL}}\right)^{\beta} \times\left(\frac{\mathrm{PA}}{\mathrm{KL}}\right)^{\chi}
$$

where $X$ is the crop output, KL the homogeneous land input, kk the input of real capital and PA the input of pesticides. $I_{\mathrm{n}}$ is the soil productivity index of nitrogen content in the TSPC (Aune and Lal, 1995). This soil productivity index varies for different crops (cashew has no limitation on nitrogen).

$I_{\mathrm{n}}^{i}=1-Q^{i} \mathrm{e}^{\left(q^{i}\left(\mathrm{NR}^{i}+\mathrm{NF}^{i}\right)\right)}$

$i=\mathrm{cot}$, cof, tob, ric, mai, sor

$$
\begin{aligned}
I_{\mathrm{n}}^{i} & =q_{1}^{i}+q_{2}^{i}\left(\mathrm{NR}^{i}+\mathrm{NF}^{i}\right)+q_{3}^{i}\left(\mathrm{NR}^{i}+\mathrm{NF}^{i}\right)^{2} \\
i & =\text { tea, cas, bea, occ }
\end{aligned}
$$

$\mathrm{NR}$ is the supply of mineralised nitrogen $(\mathrm{kg} / \mathrm{ha})$ from natural processes and NF nitrogen from chemical fertilisers $(\mathrm{kg} / \mathrm{ha})$. Before substituting this $I_{\mathrm{n}}$ function into the production function, we separate the effects coming from NR and NF by approximating the soil productivity indicator in the following manner:

$I_{\mathrm{n}}=\left(a_{0}+a_{1} \times \mathrm{NR}\right) \mathrm{NF}^{\left(b_{0}+b_{1} \times \mathrm{NR}\right)}$

where $a$ 's and $b$ 's are fixed coefficients. This function is then incorporated in the production function

$$
\begin{aligned}
\frac{X}{\mathrm{KL}}= & \mathrm{bb}^{\prime}\left(a_{0}+a_{1} \times \mathrm{NR}\right) \mathrm{NF}^{\left(b_{0}+b_{1} \times \mathrm{NR}\right)} \\
& \times\left(\frac{L}{\mathrm{KL}}\right)^{\alpha}\left(\frac{\mathrm{kk}}{\mathrm{KL}}\right)^{\beta}\left(\frac{\mathrm{PA}}{\mathrm{KL}}\right)^{\chi}
\end{aligned}
$$


But the definition of fertiliser nitrogen use is kilograms per hectare and we utilise other measurements for both variables, i.e. homogeneous land (KL) and monetary units of fertilisers $(F)$. So we have to convert this by a transfer coefficient $\varphi$ which reflects both the nitrogen content and the units of land:

$$
\varphi \frac{F}{\mathrm{KL}}=\mathrm{NF}
$$

This is put in the production function, and we simplify further by assuming that the fertiliser dependent exponent is fairly stable over the relevant range of levels for our analysis, i.e.

$b_{0}+b_{1} \times \mathrm{NR}=\bar{b}$

Hence,

$$
\begin{aligned}
\frac{X}{\mathrm{KL}}= & \mathrm{bb}^{\prime}\left(a_{0}+a_{1} \times \mathrm{NR}\right) \varphi^{\left(b_{0}+b_{1} \times \mathrm{NR}\right)} \\
& \times\left(\frac{L}{\mathrm{KL}}\right)^{\alpha}\left(\frac{\mathrm{kk}}{\mathrm{KL}}\right)^{\beta}\left(\frac{\mathrm{PA}}{\mathrm{KL}}\right)^{\chi}\left(\frac{F}{\mathrm{KL}}\right)^{\bar{b}}
\end{aligned}
$$

We want to replace the technical productivity parameters (from the soil experiments) to be consistent with the use of fertilisers by profit-maximising farmers in the base year SAM, i.e. $\bar{b}=\gamma$ which is the input cost share.

Then, we use the homogeneity of Degree 1 assumption, i.e. $\mu=1-\alpha-\beta-\chi-\gamma$ :

$$
\begin{aligned}
X= & \mathrm{bb}^{\prime} \times\left(a_{0}+a_{1} \times \mathrm{NR}\right) \times \varphi^{\left(b_{0}+b_{1} \times \mathrm{NR}\right)} \\
& \times L^{\alpha} \times \mathrm{kk}^{\beta} \times \mathrm{PA}^{\chi} \times F^{\gamma} \times \mathrm{KL}^{\mu}
\end{aligned}
$$

Then, we want to normalise the parts dependent on nitrogen from natural processes:

$\mathrm{bb}^{\prime}=\frac{\mathrm{bb}}{\text { bbnorms }}$

$\mathrm{bb}$ is the calibration constant from the SAM and bbnorms equal to $\left(a_{0}+a_{1} \times \mathrm{NR}_{1990}\right) \varphi^{\left(b_{0}+b_{1} \times \mathrm{NR}_{1990}\right)}$. Then, the part of the production function dependent on the nitrogen from natural processes is reduced to the productivity parameter

$$
\text { bbhat }_{t}=\mathrm{bb} \frac{\left(a_{0}+a_{1} \times \mathrm{NR}_{t}\right) \varphi^{\left(b_{0}+b_{1} \times \mathrm{NR}_{t}\right)}}{\text { bbnorms }}
$$

and the production function

$$
X=\text { bbhat } \times L^{\alpha} \times \mathrm{kk}^{\beta} \times \mathrm{PA}^{\chi} \times F^{\gamma} \times \mathrm{KL}^{\mu}
$$

\section{References}

Alfsen, K.H., Bye, T., Glomsrød, S., Wiig, H., 1997. Soil degradation and economic development in Ghana. Environ. Develop. Econ. 2, 119-143.

Alfsen, K.H., de Franco, M.A., Glomsrød, S., Johnsen, T., 1996. The cost of soil erosion in Nicaragua. Ecol. Econ. 16, 129-145.

Aune, J.B., Massawe, A., 1998. Effects of soil management on economic return and indicators of soil degradation in Tanzania: a modelling approach. Adv. GeoEcology 31, 37-43.

Aune, J.B., Lal, R., 1995. The Tropical Soil Productivity Calculator - a model for assessing effects of soil management on productivity. In: Lal, R., Steward, B.A. (Eds.), Soil Management: Experimental Basis for Sustainability and Environmental Quality, Advances in Soil Science. CRC Press, Boca Raton, FL.

Aune, J.B., Kullaya, I.K., Kilasara, M., Kaihura, F.S.B., Singh, B.R., Lal, R., 1998. Consequences of soil erosion on soil productivity and its restoration by soil management in sub-Saharan Africa. In: Lal, R. (Ed.), Soil Quality and Agricultural Sustainability. Ann Arbor Press, Chelsea, MI, USA, pp. 197-212.

Balsvik, R., Brendemoen, A., 1994. A Computable General Equilibrium Model for Tanzania - Documentation of the Model, the 1990 Social Accounting Matrix and Calibration, Report 94/20, Statistics Norway, Oslo.

Barbier, B., 1998. Induced innovation and land degradation: results from a bioeconomic model of a village in West Africa. Agric. Econ. 19, 15-25.

Barbier, B., Bergeron, G., 1999. Impact of policy interventions on land management in Honduras: results of a bioeconomic model. Agric. Syst. 60, 1-16.

Barret, S., 1997. Microeconomic responses to macroeconomic reforms: the optimal control of soil erosion. In: Dasgupta, P., Mäler, K.G. (Eds.), The Environment and Emerging Development Issues, Vol. 2. Oxford University Press, Oxford, pp. 482-501.

Copeland, B.R., 1994. International trade and the environment: policy reform in a polluted small open economy. J. Environ. Econ. Manage. 26, 44-65.

Coxhead, I., 2000. Consequences of a food security strategy for economic welfare, income distribution and land degradation: the Philippine case. World Develop., in press.

Coxhead, I., Jayasuriya, S., 1995. Trade and tax policy reform and the environment: the economics of soil erosion in developing countries. Am. J. Agric. Econ. 77, 631-644.

Coxhead, I., Shively, G.E., 1996. Some Economic and Environmental Implications of Technical Progress in Philippine Corn Agriculture: an Economy-Wide Perspective, Staff Paper Series, Agriculture and Applied Economics, Madison, WI.

Eriksson, G., 1991. Marked Oriented Reforms in Tanzania an Economic System in Transition, Report 27/91, Stockholm School of Economics, Stockholm.

Eriksson, G., 1993. Peasant Response to Price Incentives in Tanzania - a Theoretical and Empirical Investigation, Research report No. 91, The Scandinavian Institute of African Studies, Uppsala. 
Foltz, J.C., 1995. Multiattribute assessment of alternative cropping systems. Am. J. Agric. Econ. 77, 408-420.

Glomsrød, S., Monge, M.D.A., Vennemo, H., 1997. Structural Adjustment and Deforestation in Nicaragua. Discussion Papers No. 193, Statistics Norway, Oslo.

Grepperud, S., Wiig, H., 1999. Maize Trade Liberalisation vs. Fertilizer Subsidies in Tanzania: a CGE Model Analysis with Endogenous Soil Fertility, Discussion Paper No. 249, Statistics Norway, Oslo.

Hofkes, M.W., 1996. Modelling sustainable development: an economy-ecology integrated model. Econ. Modelling 13, 333353

Innes, R., Ardila, S., 1994. Agricultural insurance and soil depletion in a simple dynamic model. Am. J. Agric. Econ. 76, 371384

Kruseman, G., Bade, J., 1998. Agrarian policies for sustainable land use: bio-economic modelling to assess the effectiveness of policy instruments. Agric. Syst. 58, 465-481.

Lopez, R., 1994. The environment as a factor of production: the effects of economic growth and trade liberalization. J. Environ. Econ. Manage. 27, 163-184.

Pender, J.L., 1998. Population growth, agricultural intensification, induced innovation and natural resource sustainability: an application of neoclassical growth theory. Agric. Econ. 19, 99-112.

Persson, A., Munasinghe, M., 1995. Natural resource management and economywide policies in Costa Rica: a computable general equilibrium (CGE) modelling approach. World Bank Econ. Rev. 9, 259-285.
Pimentel, D., Harvey, C., Resosudarmo, P., Sinclair, K., Kurz, D., McNair, M., Crist, S., Shpritz, L., Fitton, L., Saffouri, R., Blair, R., 1995. Environmental and economic costs of soil erosion and conservation benefits. Science 267, 1117-1123.

Ruben, R., Moll, H., Kuyvenhoven, A., 1998. Integrating agricultural research and policy analysis: analytical framework and policy applications for bio-economic modelling. Agric. Syst. 58, 331-349.

Unemo, L., 1993. Environmental Impact of Governmental Policies and External Shocks in Botswana: a CGE Model Approach, Beijer Discussion Paper Series 26. Beijer Institute, Stockholm.

Vickner, S.S., Hoag, D.L., Frasier, W.M., Ascough II, J.C., 1998. A dynamic economic analysis of nitrate leaching in corn production under nonuniform irrigation conditions. J. Am. Agric. Econ. 80, 397-408.

Williams, J.R., Jones, C.A., Dyke, P.T., 1987. EPIC, the erosion productivity impact calculator, US Department of Agriculture, Agricultural Research Service, Economics Research Service and Soil Conservation Service, Temple, TX.

World Bank, 1991. Tanzania Economic Report - Towards Sustainable Development in the 1990s, Report No. 9352-TA, World Bank, Washington, DC.

World Bank, 1994. Tanzania - Agriculture, Country study, World Bank, Washington, DC.

World Bank, 1996. Tanzania. The Challenge of Reforms: Growth, Income and Welfare, Report No. 14982-TA, World Bank, Washington, DC. 